ROBERT J. SHILLER

Yale University

\title{
Public Resistance to Indexation: A Puzzle
}

THE INDEXATION OF payments makes excellent sense for all sorts of long-term contracts. Future payments should not be expressed in currency units, but instead tied to an index of consumer prices or an index of wholesale prices, of wages, of incomes, or of components of income. History shows that the real value of currency units has been so unstable that it is better to use practically any one of these indexes to specify future payments in contracts than to specify payments in terms of fixed currency.

And yet there has been relatively little use of indexation, except in situations of extremely variable inflation. People seem to have a preference for specifying their obligations and opportunities, long-term as well as short-term, in local currency units. That the public should generally want to denominate contracts in currency units-despite all the evidence that it is not wise to do so and despite the obvious examples from nominal contracts of redistributions caused by unexpected inflation-should be regarded as one of the great economic puzzles of all

I thank Emre Deliveli for conducting personal and questionnaire surveys in Turkey. I also thank my other research assistants, Aslak Aunstrup, David Bilas, Texas Hemmaplardh, Taimur Khan, Chaeri Kim, Randolph Kim, Marc Lanoue, John Lippman, Bang Nguyen, Raymond Rivera, Leonidas Spiliopoulos, Jeffrey Talpins, David Trujillo, and Zaki Wahhaj. Ali Alpay, Bülent Gültekin, Eytan Halfon, William Nordhaus, Serkan Savaşoğlu, and Mark Warshawsky made helpful suggestions. I also wish to thank Perihan Üçer of the Turkish government; and participants of a workshop at the Russell Sage Foundation Summer Institute in Behavorial Economics at the University of California, Berkeley, July 24, 1996, for hammering out a number of helpful suggestions. This work was supported by a grant from the National Science Foundation, under the auspices of the National Bureau of Economic Research. 
time. The success of the U.S. Treasury's first issuance of consumer price-indexed debt in January 1997 does virtually nothing to diminish the salience of this puzzle.

It is the premise of this paper that the answer to the puzzle must be sought in terms of human behavior that is complex and situationspecific, and that many factors impinge on people's thought processes. It requires serious work to try to gain an understanding of the indexation-resistant mind set that gives rise to irrational, partly rational, and sometimes even rational reasons for avoiding indexation. The final resolution of the puzzle may not be simple. The fact that resistance to inflation indexation is a worldwide phenomenon (at least, where inflation risk is not enormous) does not argue against the complexity of the answer. People are both very complex and at the same time very similar to one another. There is, moreover, a well-developed global culture, emphasized by sociologists, that encourages similar thinking on numerous issues. ${ }^{1}$

In this paper, I first outline the argument that indexation is advisable - in case there is any doubt - and indicate its historical precedents. Next, I describe the current extent of indexation in the United States and Turkey. Turkey is chosen for comparison with the United States because it continues to have very high and variable inflation (it has not reduced inflation in recent years, as have many other high-inflation countries), and yet the indexation of contracts is rare. I then present results of a survey conducted in these two countries, by means of interviews and questionnaires, designed to explain why people are resistant to indexation. Identical questions (except for translation) were asked in both countries.

I regard the results of this endeavor as only partially successful in illuminating the nature of public resistance to indexation. I conclude with some general thoughts about this issue and offer a partial resolution of the puzzle.

\section{The Importance of Indexation}

Through much of history, price levels have been notoriously unstable over long periods of time. Table 1 shows the standard deviations of

1. See, for example, Featherstone (1990). 
Table 1. Statistics on Inflation and Real Per Capita Growth, Selected Countries

Percentage points, except as indicated

\begin{tabular}{|c|c|c|c|c|c|}
\hline \multirow[b]{2}{*}{ Country } & \multicolumn{2}{|c|}{$\begin{array}{c}\text { Standard deviation of } \\
\text { inflation }^{\mathrm{b}}\end{array}$} & \multicolumn{2}{|c|}{$\begin{array}{l}\text { Standard deviation of } \\
\text { growth }^{\mathrm{c}}\end{array}$} & \multirow[b]{2}{*}{$\begin{array}{l}\text { Inflation-growth } \\
\text { correlation }^{\mathrm{d}}\end{array}$} \\
\hline & $\begin{array}{l}\text { Ten-year } \\
\text { intervals }\end{array}$ & $\begin{array}{c}\text { Twenty-year } \\
\text { intervals }\end{array}$ & $\begin{array}{l}\text { Ten-year } \\
\text { intervals }\end{array}$ & $\begin{array}{c}\text { Twenty-year } \\
\text { intervals }\end{array}$ & \\
\hline Argentina & $4.0 \times 10^{8}$ & $1.1 \times 10^{12}$ & 16.0 & 20.9 & -0.48 \\
\hline Brazil & $5.2 \times 10^{8}$ & $5.3 \times 10^{10}$ & 30.1 & 29.7 & -0.31 \\
\hline Canada & 39.5 & 74.5 & 11.8 & 12.8 & 0.26 \\
\hline Chile & $3.1 \times 10^{5}$ & $4.7 \times 10^{6}$ & 14.1 & 15.3 & -0.58 \\
\hline France & 46.5 & 94.7 & 16.1 & 30.5 & -0.71 \\
\hline Germany (West) & 15.1 & 19.2 & 20.1 & 37.6 & -0.47 \\
\hline India & 43.5 & 108.5 & 14.9 & 19.1 & -0.18 \\
\hline Indonesia & $1.7 \times 10^{5}$ & $1.3 \times 10^{6}$ & 25.0 & 25.0 & -0.73 \\
\hline Italy & 125.1 & 346.2 & 17.8 & 35.6 & -0.80 \\
\hline Japan & 34.4 & 42.2 & 42.2 & 102.4 & 0.02 \\
\hline Korea & 135.7 & 618.7 & 34.1 & 54.4 & -0.19 \\
\hline Mexico & $4,291.3$ & $2.6 \times 10^{4}$ & 18.1 & 26.0 & -0.83 \\
\hline Nigeria & 213.7 & 692.6 & 66.1 & 51.2 & -0.31 \\
\hline Turkey & $1,926.2$ & $3.6 \times 10^{4}$ & 14.1 & 15.8 & -0.61 \\
\hline United Kingdom & 83.4 & 174.4 & 4.7 & 6.5 & -0.77 \\
\hline United States & 32.3 & 60.5 & 7.8 & 8.6 & -0.42 \\
\hline
\end{tabular}

Source: Author's calculations based on data from the Penn World Tables, mark 5.6 (accessed on the worldwide web page of the National Bureau of Economic Research).

a. For a given country. the standard deviation of inflation or growth is the standard deviation of an annual series of overlapping ten- or twenty-year percentage changes (not annualized). For most countries, the overlapping intervals span the period 1950-92. so that the first ten-year interval is 1950-60 and the last is 1982-92; the exceptions are Argentina (195090). Indonesia (1960-92), and Korea (1953-91).

b. Inflation is measured as the percentage change in the implicit GDP deflator.

c. Growth is measured as the percentage change in real per capita GDP.

d. Correlation between series of overlapping ten-year inflation and growth intervals.

ten- and twenty-year percentage changes in price levels for sixteen countries. The standard deviations of long-term inflation rates can be interpreted as measures of uncertainty about inflation over long horizons. Almost no econometrician presumes to forecast inflation beyond a few years; the uncertainty is truly enormous. Even in the United States, where inflation uncertainty is very low by international standards, it has made long-term nominal debt very risky in real terms. Jeremy Siegel points out that in the United States, long-term government bonds have been even riskier than stocks in terms of real twentyyear returns. ${ }^{2}$ Inflation has been very unstable for many advanced and

2. Siegel (1994, p. 34). His sample period is $1802-1992$. 
otherwise exemplary countries. One could, in fact, say that only in Germany has there been no substantial uncertainty about price levels. And there has not been any substantial change in constitutions or monetary technology since these data were collected to indicate that this historical experience is no longer relevant.

To put these numbers into perspective, one should recognize that it does not take large changes in annual inflation rates to achieve large changes in the price level over ten or twenty years. Suppose, for example, that for the next twenty years the inflation rate is equally likely to average 2 percent and 4 percent-or about plus or minus 1 percentage point from current levels, a range that is often seen between different professional forecasts of inflation for just one year ahead. Then prices are equally likely to rise by 49 percent and 119 percent in twenty years.

Table 1 also shows the standard deviations of ten- and twenty-year changes in real per capita gross domestic product for the sixteen countries. Comparison of the data in the table reveals that while both inflation and real income are unstable (and both risks should ideally be hedged), the inflation rate has been far more unstable. Because of the swings in real income, it can be argued that many payments (such as social security) should be indexed in terms of an aggregate income index rather than a price index. ${ }^{3}$ The puzzle that this paper tries to understand is the public's lack of interest in either form of indexation.

In general, in a long-term contract neither side benefits from specifying payments in terms of units of currency, since neither side benefits from pure random shocks. When there is great uncertainty about the future direction of prices, both debtors and creditors benefit from indexation. When contracts are not indexed, if inflation turns out to be much higher than expected, creditors are wiped out. If inflation turns out to be much lower than expected, debtors go bankrupt. Both of these potential problems can be prevented simply by indexing the contract when it is first written.

Indexing payments is virtually costless; only a few words need to be added to a contract and the calculations necessary to implement indexation are trivial. Because the indexation calculations are so simple, there is little avenue for legal maneuvering to avoid compliance. Since

3. See Shiller and Schneider (1995), Shiller (1993), Brainard and Dolbear (1971), Fischer (1983b), and Merton (1983). 
indexation is so nearly costless, one may regard not indexing (and so specifying future payments in units of currency) as equivalent to writing a contract that ties future payments to the outcome of a horse race or a coin toss. Why would anyone do it?

That payments in long-term contracts should be tied to some index, such as a consumer price index (CPI), has been been widely agreed on by economists for over a century and a half. According to Irving Fisher's history of thought on indexation, it was advocated in the nineteenth century by Joseph Lowe and G. Poulett Scrope. ${ }^{4}$ In 1875 William Stanley Jevons recommended that the indexation of private contracts "might be made compulsory, in the sense that every money debt of, say, more than three months' standing, would be varied according to the tabular standard [index], in the absence of an express provision to the contrary." 5 Fisher's history documents an ever increasing number of economists who advocated indexation from 1875 onward, and the number continues to grow. Recent advocates of inflation indexation include James Tobin, Milton Friedman, Stanley Fischer, and Zvi Bodie. $^{6}$

Thus the public's resistance to indexation is a great puzzle. To sum up, the effects of inflation on real payments are so enormous as to be obvious, dealing with these problems by writing indexed contracts entails almost no costs in terms of computation or legal complexity, and economists have been vocally advocating indexation. Some analysts refer to the existence of money illusion (identified by Fisher as a tendency to confuse real and nominal quantities) as a puzzle, but it is not really so. ${ }^{7}$ It should not be surprising that people often make mistakes. What is really puzzling is that nearly everyone, including educated and highly informed people, resists taking elementary steps to heed the experts' commonsense advice to use indexation.

\section{The Extent of the Puzzle}

Efforts by U.S. economists and other opinion leaders to establish a standard for the indexation of contracts have achieved success only for

4. Fisher (1934); Lowe (1822).

5. Jevons $(1875$, p. 331).

6. Tobin (1971); Friedman (1974); Fischer (1986); Bodie (1990).

7. Fisher (1928). 
a limited array of contracts and often only for short time intervals. The success of their Turkish counterparts has not, despite the high inflation in that country, been any more encouraging.

\section{The United States}

The issuance, on January 29, 1997, of the first inflation-indexed U.S. federal government bonds, the so-called TIPS (Treasury Inflation Protection Securities), ten-year bonds yielding 3.449 percent, is widely described in the media as a success. ${ }^{8}$ Indeed, the experience with these bonds hints that indexed debt might someday be a success. This first issue has prompted a few issues of private indexed debt and has spurred the Chicago Board of Trade to file for permission to trade futures and options on TIPS. But if this indexed bond issue is now, in fact, a clear success, it is so only relative to pessimistic expectations. The $\$ 7$ billion issued represents only about one-tenth of 1 percent of the U.S. federal debt. More will be issued (quarterly auctions are planned), but there is little evidence of a public clamor for indexed debt. ${ }^{9}$ Treasury Secretary Robert Rubin described demand at the first auction as "predominantly institutional. " ${ }^{10}$ Media accounts confirm that, even though the Treasury kept the minimum denomination small $(\$ 1,000)$ to attract individual investors, retail brokers report little interest from individual investors. Part of the reason for the lack of immediate public interest can be found in the media coverage. In general, reports do not seem to be written to inspire enthusiasm in individual investors. For example, Consumer Reports writes: "As attractive as the inflation-indexed notes appear, it

8. Some people may consider as indexed the bonds with gold clauses (guaranteeing payment in gold rather than dollars) that became common in the late nineteenth century, when the free-silver movement threatened massive inflation in the United States. But these were tied to another form of money, not to a price index. Moreover, the buying power of gold was quite unstable. However, there is one very early instance of true indexed bonds in the United States. In 1780, the State of Massachusetts issued bonds tied to an index of four commodity prices; see Willard Fisher (1913). This issue was refinanced by conventional debt in 1786. Apparently, protecting indexed bond holders from inflation became politically difficult to sustain at a time of widespread discontent about wartime inflation, sentiments that in Massachusetts culminated in Shay's Rebellion.

9. The second auction of TIPS, on April 8, 1997, has been described as less successful than the first. This time $\$ 8$ billion were sold, but at the higher yield of 3.65 percent.

10. “Treasury Auctions Inflation-Linked Debt,', Facts on File News Digest, January $30,1997$. 
may make sense to wait and watch instead of plunging right in.",11 These accounts have emphasized such issues as doubts about possible revisions of the Consumer Price Index; the risk that because the inflation component of TIPS is taxable, some bondholders may have to pay more in taxes on them than they receive in interest income; and the possibility that TIPS may be difficult to sell later, because the secondary market is weak. They do not seem to acknowledge the superiority of indexed bonds over nominal bonds in terms of inflation risk; the real riskiness of nominal debt appears not to be an issue for them.

There have been almost no private initiatives to issue similar bonds, nor indexed home mortgages or other kinds of indexed indebtedness. Irving Fisher persuaded the Rand Kardex Company, a company that he had helped to found, to issue indexed debt in 1925. But this first attempt at creating private indexed debt in the United States did not spur imitators. Ultimately, "after the Rand Kardex Co. was merged in a larger organization (the Remington Rand Inc.) this issue was converted into ordinary preferred stock and bonds to gain a wider market than was possible for an infamiliar form of security." $12 \mathrm{~J}$. Huston McCulloch points out that indexed debt appears to have been illegal between 1933 and 1977, but there have been no legal obstacles since. ${ }^{13}$ When inflation picked up after 1977, there was a small flurry of proposals and efforts to establish markets for indexed mortgages (for example, by the Timbers Corporation, the Utah State Retirement System, and the Fund for an Open Society) and indexed bonds (for example, by the Real Dollar Corporation and the Fund for an Open Society), but they soon disappeared with the decline in inflation rates after the recession of 198182. ${ }^{14}$ The issuance of the TIPS in January 1997 was followed, within about a week, by some private issues of indexed debt. The Tennessee Valley Authority issued $\$ 300$ million on February 5, J. P. Morgan and Co. issued $\$ 200$ million and Toyota Motor Credit Corporation issued $\$ 100$ million on February 6 , and Salomon Inc. issued $\$ 450$ million in

11. “New Inflation-Proof Bonds: Should They Be in Your Portfolio?', Consumer Reports 62, April 1997, p. 89.

12. Fisher (1934, p. 112).

13. McCulloch (1980).

14. Fischer (1983a) finds no solid reasons for the absence of privately issued indexed debt in the United States and instead falls back on two possible hypotheses: that borrowers' expectations of inflation may have been larger than those of lenders, and that the uncertainty about inflation was not great. 
CPI-linked debt on February 7. The Federal Home Loan Bank System also issued indexed debt in the wake of the TIPS. ${ }^{15}$ Yet in the following month and a half, the media reported no further indexed issues. While these private issues of indexed debt are encouraging, and one can hope that a market for privately issued indexed debt is forming, there is not yet any firm evidence that there will be a substantial amount of indexed debt in the United States in the future.

Even though the United States has historically experienced relatively low levels of uncertainty about inflation by world standards, failure to index debt has involved tremendous redistributions between debtors and creditors. Such redistributions have occurred in every period of U.S. history characterized by unanticipated inflation or deflation. For example, the last couple of decades of the nineteenth century were deflationary times, and since people did not seem to anticipate the deflation properly, debts were magnified. Farmers and other debtors, borrowing at fixed rates, tended to go bankrupt. Their dissatisfaction gave rise to the Greenback party, the Populist party, and the National Silver party, and was a dominant political force in the national elections of 1892 and 1896. William Jennings Bryan's famous "Cross of Gold" speech in 1896, which won him the nomination for the presidency, was, in effect, a plea for inflation in order to spare debtors who had been ruined by deflation. But these political movements lost their force when prices started rising again after 1896.

At the end of World War II, the U.S. federal debt was exceptionally high (for the time) because the government had borrowed rapidly and extensively to pay for the war: in 1945 it stood at $\$ 260$ billion, well over a year's gross national product. By 1951, just six years later, unanticipated postwar inflation had pushed the Consumer Price Index up by 44 percent, meaning that 30 percent of this debt had effectively been repudiated. Much of the economic cost of the war was thrown on unwitting debt holders. Likewise, whereas in 1971 a new home buyer faced a conventional fixed mortgage rate of 7.7 percent, by 1981 the price level, measured by the CPI, had risen by 124 percent. In effect, more than half of the real debt in a long-term mortgage had been forgiven-and mortgage rates reached 16.6 percent in 1981 , reflecting

15. “CPI-Linked Corporate Debt Tops $\$ 1.0$ Bln on Week,', Reuters Financial Service, February 7, 1997. 
the much higher expected inflation rates. These few examples show the magnitudes of the redistributions caused by nominal contracts.

In the United States, social security payments and military pension plans are indexed to inflation, but private pensions are not substantially indexed. The Teachers Insurance and Annuity Association and College Retirement Equities Fund (TIAA-CREF), the largest private pension fund in the country and the pension provider for U.S. colleges and universities, allows its TIAA annuitants to select between a standard and a graded annuity, of which the latter uses the Consumer Price Index to adjust payouts so that they remain more nearly constant in real terms. A standard TIAA annuitant lost almost 70 percent of the value of the annuity payment to inflation over the period 1970-95. The graded annuity was first offered in 1982, and yet by 1994 only 14 percent of TIAA annuitants were choosing this option. ${ }^{16}$

The TIAA graded annuity is not really indexed to inflation, it merely adjusts payouts so that they will be constant in real terms through time if inflation is as expected. The payout of the graded annuity depends on the returns to funds invested. Therefore when these funds are invested in fixed incomes, there will still be losses if there is unexpected inflation. In principle, the CREF offers better protection than the TIAA against inflation, but 61 percent of the TIAA and CREF life annuity and minimum distribution contracts issued in 1994 were in TIAA. ${ }^{17}$

Alimony and child support awards are other examples of very longterm contracts. Alimony often continues until one spouse dies or the spouse receiving the award remarries. Child support awards typically last through the minority of the children and through their postsecondary education. Since these contracts are often so long term and represent such a significant fraction of individual incomes, one would think that all of them would be indexed. In fact, they are only very rarely indexed to inflation. The legal literature on indexation and alimony in the United States-a literature apparently confined to the period before inflation fell in the mid-1980s-implies little use of indexation in alimony or

16. For both the loss on the standard TIAA annuity and the graded annuity, see Francis P. King, "The TIAA Graded Payment Method and the CPI," TIAA-CREF Research Dialogues 46, December 1995 (available on TIAA-CREF's worldwide web page).

17. This percentage is inferred from Francis P. King, "Trends in Selection of TIAACREF Life-Annuity Income Options, 1978-1994,'” TIAA-CREF Research Dialogues 48, July 1996, table 6 (available on TIAA-CREF's worldwide web page). 
child support. ${ }^{18}$ To confirm that indexation is still rare in this arena, my research assistant telephoned six divorce lawyers and asked, "What percent of alimony agreements are indexed to inflation?' Four of the six answered none. Two answered that they had seen such agreements, but not recently.

Child support payments are often partially indexed, to the extent that they specify that the noncustodial parent must pay for medical insurance, life insurance, and education. However, as noted by legal scholar Robert Wilson: "As judicial policy has developed, it has not required that similar protection be extended to the monthly cost of raising the children. . . . The court decree does not require that the noncustodial parent bear his or her fair share of the cost of future inflation. The court is cognizant of the impact of inflation; it has recognized the problem of increases in the cost of living for more than fifty years. . . [Yet] it seems that the courts presently include a COLA [cost of living allowance] provision to protect the child support order from inflation only when the parties have so agreed in a stipulation." ${ }^{19}$ Change in the real value of alimony payments can be overcome only by costly and difficult to obtain modifications made by divorce courts.

Long-term option or warrant strike prices are only rarely indexed. Futures contracts could be designed so that hedgers would be protecting the real value of their inventories, rather than the nominal value, but they never are.

The absence of indexation schemes may also be responsible for a relative dearth of fixed long-term contracts in the United States. If one is constrained to write contracts in nominal terms, then one might logically keep all contracts short or include various escape clauses (such as call provisions or refinancing options) that effectively shorten contracts. It is difficult to measure the extent of benefits that might accrue if long-term contracts defined in fixed real terms were widely accepted. Since indexation has never been widespread, the potential welfare improvements that such contracts might provide have never emerged.

The indexation of wages became widespread in the United States during World War I, but was dropped in the 1920s, a period of stable

18. See, for example, Cynthia C. George, "Combatting the Effects of Inflation on Alimony and Child Support Orders,' Connecticut Bar Journal 57(3), 1983, pp. 223-35.

19. Wilson (1980, pp. 137-38). 
prices. ${ }^{20}$ It was revived in the inflation of the 1970 s, but appears to have fallen sharply since the deep recession of 1981-82, when firms were unable to cut real wages, despite stagflation. ${ }^{21}$ The aversion to wage indexation currently expressed by firms when negotiating with labor might be interpreted as a recognition of the importance of applying a little "grease" to the wheels of the labor market. Some obfuscation of the stark realities may help people to accept changes in real income more easily.

Indexation of wages and salaries really ought to be considered in a special category, not entirely parallel to indexation of the other kinds of contracts discussed above. Possibly, it appears problematical because of the emotions and comparisons with nominal standards that have entered the rhetoric and politics of wage bargaining. The indexation of wages and salaries has been blamed for the structural inflation seen in Latin American countries. ${ }^{22}$ Moreover, people seem to have a pathological aversion to seeing wage cuts on paper, even though real wage cuts concealed by inflation are acceptable. ${ }^{23}$

With the possible exception of labor markets, where the use of indexation is clouded by other considerations, the history of the United States largely seems to be one of missed opportunities for indexation.

\section{Turkey}

Countries that have experienced high and variable inflation, such as Argentina, Brazil, and Chile, have often widely adopted indexation for long-term contracts. This is not surprising; under such circumstances, the defects of long-term nominal contracts ought to be extremely obvious. And yet there are still other countries with high and variable inflation, such as Turkey, that do not index to any substantial degree. ${ }^{24}$

In 1995, when the Turkish consumer price index showed an inflation rate of 88.1 percent, only three of the 104 countries for which data are

20. See Fisher (1934).

21. See Robert S. Gay, "Union Settlements and Aggregate Wage Behavior in the 1980s,"' Daily Labor Report 235, p. D-1, December 6, 1984.

22. See Cavallo (1983).

23. See Groshen and Schweitzer (1995), Akerlof, Dickens, and Perry (1996), and Card and Hyslop (1997).

24. Inflation in Turkey, although massive, has not quite reached the hyperinflationary proportions seen in Argentina or Brazil in the past couple of decades. Some observers believe that it is the lack of indexation that has enabled Turkey to avoid real hyperinflation. 
given in the International Monetary Fund's International Financial Statistics had higher inflation rates: Zaire, Suriname, and Russia (which has since tamed the inflation). The problem one faces in studying high inflation in the 1990s is that most countries that experienced high inflation in the postwar period have reduced it dramatically; inflation is down throughout most of the world. In Turkey, however, inflation has not been below 20 percent per year since the late 1970s. It has also been extremely variable, as table 1 shows. All forms of indexed contracts have been legal in Turkey since January 1980, when Turgut Özal, undersecretary to Prime Minister Süleyman Demirel, liberalized the economy.

Certain prices in Turkey are now commonly quoted in U.S. dollars or deutsche marks. In the newspapers of major cities, house prices are almost always advertised in dollars. By contrast, in small towns house prices are mostly quoted in Turkish lira (TL). The same is true of apartment rents: large urban and wealthy areas favor dollars or deutsche marks and more rural areas, Turkish lira. The prices of commercial real estate and expensive electronic goods are often set in dollars. Overall, though, the great majority of prices are set in Turkish lira.

Currency exchanges are widespread in Istanbul, about as common as fast food restaurants. Many people carry U.S. dollars or deutsche marks, but instead of paying in these foreign currencies, they convert them into Turkish lira at the last possible minute, even for small expenditures. In some cases, a person may even exchange currency before going to the movies.

The Turkish government had never issued inflation-indexed debt before late February 1997, when the equivalent of U.S. \$148.9 million was issued to the public. ${ }^{25}$ Turkish news media have apparently shown little interest, and there was reportedly "low participation" in the issue.$^{26}$ In April 1994, as part of a stabilization program, the government

25. The Turkish government unsuccessfully attempted to market indexed bonds in 1996.

26. One explanation offered by the media for the poor showing of the Turkish indexed bonds runs as follows: "Inflation and political woes also hampered the treasury's sale of two-year inflation-indexed bonds. . . . The timing of the first inflation-indexed bond auction was not good. Political uneasiness, higher-than-expected inflation data, falling stocks, rising bond yields lowered demand for the auction,' said a private bank treasurer.' (Tulin Aygunes, “Turkish Bond Yields Jump on Politics, Inflation,', Reu- 
advised banks to create one-year time deposits linked to the Turkish wholesale price index ('TEFE'). Turkish banks now advertise, alongside a variety of nominal interest rate accounts, these TEFE + savings accounts.

To gauge the status of indexation in Turkey, my research assistant Emre Deliveli interviewed a number of people in Istanbul, including ten lawyers who handle divorce cases, ten bond dealers, and three labor union officials. These interviews reveal that indexation is almost never used for alimony or child support payments, corporate bonds, or labor contracts. Instead, the problems caused in nominal contracts by inflation are dealt with by effectively keeping the contracts short. Alimony and child support payments are regularly modified by their courts, despite the costs and conflicts, just as in the United States. Debt and labor contracts are for the short term.

When asked about public resistance to indexation, Turkish interviewees were not often clear. Sometimes they cited mistrust of the price index and concerns that even if the index were correct, people might not be able to pay the higher payments resulting from indexation. None of them knew of any tax disadvantages to indexation. Some said that lack of understanding is not an issue; everyone understood indexation perfectly well.

Respondents judged that dollarization is used for about 10 percent of alimony and child support settlements, particularly for more wealthy clients, but that corporate bonds and labor contracts are not dollarized at all. One explanation offered as to why dollarization is not used more widely is that the exchange rate has been unstable. One respondent said that the Turkish lira fell from 9,000 to the dollar to 40,000 to the dollar in a matter of days. While this statement is an exaggeration (it took a couple of years, not days), the real buying power of the U.S. dollar has, in fact, been very variable in Turkey. For example, according to government CPI and exchange rate figures, it increased by 57 percent between 1993 and 1994. The resultant change in local real values in a dollarized contract would have been enormous.

ters Financial Service, March 4, 1997.) The government has issued small quantities of debt tied to foreign exchange in the past, starting with the Turkish Prime Ministry Public Participation Fund in 1987. 


\section{Addressing the Puzzle}

It would seem to be easy to tell why nobody is interested in indexation: just ask your neighbor. The answers should be immediate. And yet the economics profession apparently does not have a good understanding of the issue. It is the thesis of this paper that the reasons for the lack of public interest in indexation are not so easily discerned. People do not initially remember how they have arrived at their opinions; one must work with them. What may, at first, seem to be gutlevel prejudices or impulsive rejections ultimately derive from a constellation of views and assumptions, the full implications of which must be worked out before one can achieve real understanding.

\section{Informal Interviews}

The first step in addressing the puzzle of public resistance to indexation was to obtain an informal impression of public opinion through personal interviews. A dozen Yale University students selected people in the New Haven area at random to interview about inflation. The students called random listings in the telephone book and also interviewed passers-by in a shopping mall, students in a vending machine area at a Yale library, workers striking Yale University on the street, and the employees of a local restaurant, several of whom were Turkish. Some students also did some library research on views on indexation. I met with the students, individually and in groups, every week or so for a semester to discuss what we were learning and to hammer out questions for formal questionnaires. This informal interview stage of the project was very important, for we listened to the issues that people brought up and were able to pose follow-up questions; that is, to pursue their lines of argument. It also made for much improved questionnaires, since we got an advance look at people's reactions to the questions and whether they were misinterpreting them.

One of the most striking findings from the responses to the informal interviews is that many, though by no means all, people seem to have a visceral resistance to indexation: they trust dollars, not formulas. Several respondents said, "I want to know how much money I will be getting." It was also commonly said that "the indexed plan is too risky," as if people regard the prospect of getting fewer dollars as a 
bad outcome, even though this would occur only if prices were also low. ${ }^{27}$ But much more than such impulse reactions must be at work to prevent any substantial public acceptance of indexation.

\section{Questionnaire Design}

The second step of the project was to design formal questionnaires. Many of the questions that I wanted to ask about indexation could not be asked without posing leading questions, which suggested concepts that might not otherwise be on people's minds. Therefore, in order to discern whether people were merely being very agreeable, two sets of questions were used in the United States, questionnaires A and B. Most questions appear on both, but with different, often opposite, wording. Only questionnaire A was used in Turkey, since this is sufficient for international comparison.

Some questions are included in both questionnaires A and B with identical wording. In these cases, the ordering of the multiple choice answers is always reversed in questionnaire B, except for the no opinion category, which is always last. In the discussion below, the ordering shown for these questions is that of questionnaire A. Some questions cannot be translated into Turkish literally because of the different conditions in Turkey, notably, the much higher inflation. Below, any substantial differences are indicated in square brackets. I discuss the questions in the order in which they appear on the questionnaires, not in order of importance.

Random samples from all over the United States, derived from telephone books, were purchased from Survey Sampling, Inc., and a random sample from the town of Marmaris, Mugla, Turkey, was extracted from the local telephone book. Marmaris lies on the west coast of Turkey, a region with somewhat higher levels of income and education than the national average.

For each of the three types of questionnaire- "USA-A," "Turkey,"' and 'USA-B', - four hundred copies were initially mailed out with a letter explaining the social purpose of the survey and informing participants that their responses might help to formulate public policy toward indexation. A few weeks later, a second letter and replacement

27. Fisher $(1928,1934)$ makes similar observations about public reactions to proposals for indexation. 
questionnaire was sent out to all who had not responded to the first. In the United States, a third letter and replacement questionnaire were sent out to those still failed to respond.

There were 140 responses ( 35 percent) to questionnaire $\mathrm{A}$ in the United States, 161 responses (40 percent) to questionnaire B in the United States, and 99 (25 percent) responses to questionnaire A in Turkey, giving a total of four hundred responses, or an overall response rate of one-third. There were fewer responses in Turkey because the questionnaire was only mailed twice. The response rate is not as high as one would like but, given the difficulty of the questionnaire and the subject matter, one might not be able to do better.

The characteristics of the respondents are shown in table 2. The level of education is high. It is possible that it would be difficult to survey the opinions of the uneducated, less sophisticated fraction of the population. Perhaps the opinions of the more educated and sophisticated people are most salient, since they tend to be the opinion leaders and to advise friends and relatives who are less informed about contracts and investments.

\section{Money Illusion and the Framing of Questions}

It should be noted at the outset that money illusion is one factor that reduces interest in indexation. Fisher finds that people show little awareness of the effects of aggregate price level changes on their lives and have a tendency to think in terms of quantities measured in local currencies as standards of value. ${ }^{28}$ Eldar Shafir, Peter Diamond, and Amos Tversky confirm empirically that given calculations presented in dollars, people tend to choose stable dollar amounts, and given calculations presented in real goods and services, they tend to choose stable real amounts.$^{29}$ That answers to questionnaire items are affected by the wording of the questions and by associations that the wording suggests is well known to psychologists: "framing"' affects responses.

Shafir, Diamond, and Tversky also show that people seem to have a preference for receiving nominal pay increases, even if they know that prices have gone up just as much. The authors base this finding on comparisons of choices made in scenario questions across groups of

28. Fisher (1928).

29. Shafir, Diamond, and Tversky (1997). 
Table 2. Characteristics of Survey Respondents

Percent, except as indicated

\begin{tabular}{|c|c|c|c|}
\hline \multirow[b]{2}{*}{ Characteristic } & \multicolumn{3}{|c|}{ Questionnaire } \\
\hline & $U S A-A$ & $U S A-B$ & Turkey \\
\hline \multicolumn{4}{|l|}{ Sex } \\
\hline Male & 75 & 75 & 80 \\
\hline Female & 25 & 25 & 20 \\
\hline \multicolumn{4}{|l|}{ Birth year } \\
\hline $1970-79$ & 5 & 3 & 21 \\
\hline $1960-69$ & 16 & 11 & 35 \\
\hline $1950-59$ & 23 & 21 & 21 \\
\hline $1940-49$ & 26 & 23 & 18 \\
\hline $1930-39$ & 12 & 15 & 3 \\
\hline $1920-29$ & 12 & 17 & 2 \\
\hline $1910-19$ & 7 & 8 & 0 \\
\hline Before 1910 & 1 & 1 & 0 \\
\hline \multicolumn{4}{|l|}{ Educational attainment } \\
\hline Less than high school graduate & 4 & 7 & 9 \\
\hline High school graduate & 24 & 17 & 14 \\
\hline Some college & 25 & 24 & 17 \\
\hline College graduate & 30 & 28 & 44 \\
\hline Graduate or professional school & 17 & 23 & 16 \\
\hline \multicolumn{4}{|l|}{ Annual income } \\
\hline Less than $\$ 25,000^{\mathrm{a}}$ & 11 & 21 & 29 \\
\hline$\$ 25,000-\$ 70,000^{\mathrm{b}}$ & 67 & 55 & 47 \\
\hline More than $\$ 70,000^{c}$ & 21 & 24 & 24 \\
\hline Number of respondents & 140 & 161 & 99 \\
\hline
\end{tabular}

Source: Author's survey.

a. In Turkey, less than 600 million Turkish lira (TL).

b. In Turkey, 600 million TL to 3 billion TL.

c. In Turkey, more than 3 billion TL.

respondents. I attempt, elsewhere, to replicate their findings in a much less subtle way, by asking directly about this tendency, and I compare the answers of randomly selected people with those of professional economists at major universities. ${ }^{30} \mathrm{I}$ ask:

Do you agree with the following statement? "I think that if my pay went up I would feel more satisfaction in my job, more sense of fulfillment, even if prices went up just as much.'" [Please indicate how much you agree, on a scale from 1 to 5.]

30. Shiller (1997). 
Response in percent

$\begin{array}{lcrcccc} & \begin{array}{c}\text { l: fully } \\ \text { agree }\end{array} & 2 & \begin{array}{c}3: \\ \text { undecided }\end{array} & 4 & \begin{array}{c}\text { 5: completely } \\ \text { disagree }\end{array} & \begin{array}{c}\text { Sample } \\ \text { size }\end{array} \\ \text { US-All } & 28 & 21 & 11 & 14 & 27 & 112 \\ \text { Economists } & 0 & 8 & 3 & 13 & 77 & 79\end{array}$

While most of the "US-All" sample of noneconomists did not fully agree with the statement, about half of them chose answers 1 or 2. It is striking that so many would agree, since this question is essentially asking them to admit to irrational behavior. Some of the noneconomists wrote remarks on the questionnaire, saying that they knew that it was irrational to choose answers 1 or 2 , but they wanted to do so anyway. In contrast, most of the economists completely disagreed with the statement.

It is difficult to say to what extent the anomalies of judgment that such money illusion produces are responsible for public apathy toward indexation. If the dependence of answers on framing is the result of casual errors made by respondents who are only marginally interested in answering correctly, then it is perhaps unlikely to be solely responsible for the widespread apathy to indexation. If there is satisfaction in receiving nominal pay increases, even if prices go up as much, it may still be that when people think seriously about major economic decisions, they set aside such feelings. Advocates of indexed contracts make an effort to frame the discussion in a way that encourages support, and presumably opinion leaders who take more time to think about the issues may prevent people from acting wrongly because of casual errors.

It is my hypothesis that more is at work in producing apathy toward indexation than simple money illusion. Money illusion just does not seem to be strong enough to prevent people from taking steps to protect their own welfare when they really understand the importance of the issue. In a sober and collected moment, people ought to be able to make correct decisions about indexation. To resolve the puzzle, it is necessary to characterize further the worldview that makes it difficult to convince people of the importance of indexation, even when their attention is focused on the subject and the framing issues are explained to them. 


\section{A Preliminary Exercise on Indexation}

A fundamental problem of designing a questionnaire for this study is that inflation and indexation are complicated concepts, which people may think that they understand but, in fact, do not. As a researcher, one must decide whether one is interested in people's answers from their current state of mind or in the answers that they give after one has forced them to confront what these terms mean, thereby educating them about the basic definitions and issues. And how does one know if they understand them?

This study is primarily interested in the more informed judgments that people make after some thought. The questionnaires begin with a brief description of the issues and then quiz respondents on the mathematics of indexation. Making respondents work problems on indexation forces them to come to grips with the issues and also allows one to assess whether they do understand the issues. A disadvantage of this method is that it reduces response rates, by intimidating many who might otherwise respond.

All three versions of the questionnaire begin with the following explanation:

In this questionnaire we seek your opinions on the subject of inflation and indexation.

By inflation, we mean the rate of increase in the cost of living (of the average price of goods and services you buy, of the Consumer Price Index) as computed from data on actual prices.

By indexation, we mean agreeing now to tie the amounts of money you will receive or pay at future dates to the inflation rates the government announces in the future, so as to preserve real buying power. We say then that the payments are "indexed," or that there is an "Escalator Clause" or a "Cost of Living Allowance (COLA)."

Example of Indexation: Mr. Smith [Ahmet Bey] who is retiring right now chooses a pension that is fully indexed to inflation. He is promised $\$ 1,000$ a month in today's dollars [20 million a month in today's Turkish lira], indexed to inflation. If inflation turns out to be 5 percent [50 percent] over the next year, he will be getting $\$ 1,050$ [30 million TL] a month next year. If inflation turns out to be -5 percent [ -50 percent] over the next year (prices are falling) he will be getting $\$ 950$ [10 million $\mathrm{TL}]$ a month next year.

Immediately after this example, the following question is posed: 
1(A, B). If inflation was 3 percent [75 percent] over the past year, then by definition this means that:

[Please circle one number]

1. If we look at prices of many different things, 3 percent 75 percent] of them are too high.

2. Prices are on average 3 percent $[75$ percent] higher than they were last year

3. Wages are on average 3 percent [ 75 percent] higher than they were last year

4. Prices are going up 3 percent [ 75 percent] more than wages are

5. Do not know

Response in percent

$\begin{array}{lcccccc} & & & & & & \text { Sample } \\ \text { USA-A } & 3 & 2 & 3 & 4 & 5 & \text { size } \\ \text { USA-B } & 1 & 84 & 1 & 12 & 1 & 138 \\ \text { Turkey } & 6 & 79 & 0 & 17 & 3 & 159 \\ & & 5 & 15 & 1 & 97\end{array}$

From the answers to this question, it seems very clear that most people in both countries understood what inflation is after reading the introduction. The tendency of some to select answer 4 reveals that some might, in effect, define inflation as a decrease in real wages. Still, no more than one in six chose this answer.

Respondents are then asked to work mathematical problems in order to test their understanding of indexation:

2(A, B). Ms. Walter [Ayşe Hanım] is disabled, and is living off of fully indexed disability plan income. In 1996 she is receiving \$500 [5 million TL] a month in disability payments. If inflation turns out to be 10 percent [50 percent] between 1996 and 1997, then in 1997 she will be receiving:

1. $\$ 450$ [2.5 million TL]

2. $\$ 500$ [5 million TL]

3. $\$ 550[7.5$ million TL]

4. Do not know

Response in percent

$\begin{array}{llcccc} & & & & & \text { Sample } \\ \text { USA-A } & 1 & 2 & 3 & 4 & \text { size } \\ \text { USA-B } & 4 & 2 & 94 & 1 & 139 \\ \text { Turkey } & 3 & 1 & 94 & 3 & 160 \\ & 2 & 4 & 91 & 3 & 98\end{array}$


3(A, B): If inflation turns out to be -10 percent [ -50 percent] (prices falling) then in 1997 Ms. Walter [Ayşe Hanım], with her fully indexed plan, will be receiving:

1. $\$ 450[2.5$ million TL]

2. $\$ 500[5$ million TL]

3. $\$ 550[7.5$ million TL]

4. Do not know

Response in percent

$\begin{array}{lccccc} & & & & & \text { Sample } \\ \text { USA-A } & I & 2 & 3 & 4 & \text { size } \\ \text { USA-B } & 94 & 2 & 4 & 1 & 140 \\ \text { Turkey } & 85 & 7 & 2 & 6 & 161 \\ & 76 & 17 & 4 & 3 & 99\end{array}$

Respondents did remarkably well on both questions, giving correct answers most of the time. Some Turkish respondents seemed to have a little difficulty in dealing with a situation in which prices fall by 50 percent in a year and imagining that payments might be cut in half in nominal terms, but overall the responses support the notion that people understand indexation.

The following question is intended to confirm that, after working these problems, respondents understand that indexation does preserve real values:

$4(\mathrm{~A}, \mathrm{~B})$. In the above question, if all prices really fall 10 percent [50 percent] in 1997, what, in theory, ought to be the change between 1996 and 1997 in the real buying power of Ms. Walter's [Ayşe Hanım's] indexed disability income?

1. In 1997 she can buy more goods and services than in 1996

2. She can buy exactly the same amount in both years

3. In 1997 she can buy less goods and services than in 1996

4. Do not know

Response in percent

$\begin{array}{lccccc} & & & & & \text { Sample } \\ \text { USA-A } & 1 & 2 & 3 & 4 & \text { size } \\ \text { USA-B } & 15 & 76 & 9 & 1 & 139 \\ \text { Turkey } & 18 & 70 & 10 & 3 & 156 \\ \text { 39 } & 49 & 11 & 0 & 99\end{array}$

Three-quarters of the United States respondents and half of the Turkish respondents chose the correct answer, 2. It is curious that among those 
who answered otherwise, there was a definite bias toward the belief that the indexed contract provides more goods and services (answer 1). This could be a sign of a powerful tendency to think in nominal terms, even after working the mathematical problems correctly. There is, however, another possible interpretation: people do not believe that the price index does what it is said to do. Moreover, although the survey does not sample economists, they would probably also show some tendency to pick answer 1, because of the substitution effect. Both of these issues are discussed below.

The overall interpretation of the results presented above is that respondents, by and large, had little trouble with the basic concepts of indexation, at least after they were explained to them. Most of them understood that indexation preserves real buying power rather than nominal quantities. This does not mean that people are always ready to give such enlightened answers. Media accounts of indexation schemes rarely, if ever, give as thorough an explanation of the essential quantitative concepts regarding indexation as the questionnaires used in this study.

\section{Direct Questions}

When asked directly whether they would choose an indexed contract, most respondents said that they would:

5(A). Imagine that you are in Ms. Walter's [Ayşe Hanım's] situation. Experts' best guess is that there will be 3 percent [ 25 percent] a year inflation indefinitely, but really they aren't sure. Which disability income plan would you prefer?

1. The indexed plan as with Ms. Walter [Ayşe Hanım] (tied to future inflation rates as computed from data on actual future prices by government statisticians)

2. An unindexed plan that increases payments 3 percent [ 25 percent] a year, regardless of inflation

3. I am indifferent between the two plans or don't know

Response in percent

$\begin{array}{lcccc} & & & & \text { Sample } \\ \text { USA-A } & I & 2 & 3 & \text { size } \\ \text { Turkey } & 65 & 29 & 7 & 136 \\ & 85 & 9 & 6 & 86\end{array}$


The majority of respondents, after having answered the preceding questions, chose indexation. The substantial minority that did not can provide insights into public resistance to indexation. It is important to note that those in the USA-A sample who chose answer 2, the unindexed plan, were almost as likely to answer question 4 correctly as the overall sample: 67 percent of those who chose answer 2 for question 5 also chose answer 2 to question 4 (of the entire U.S. sample, 73 percent chose answer 2 for question 4).

When the inflation rate built into the unindexed plan was changed from 3 to 10 percent and the unindexed plan was placed first in the list of answers, more people still chose the indexed plan than the unindexed plan:

5(B). Imagine that you are in Ms. Walter's situation. Experts' best guess is that there will be 10 percent a year inflation indefinitely, but really they aren't sure. Which disability income plan would you prefer?

1. An unindexed plan that increases payments 10 percent a year, regardless of inflation

2. The indexed plan as with Ms. Walter (tied to future inflation rates as computed from data on actual future prices by government statisticians)

3. I am indifferent between the two plans or don't know

Response in percent

$\begin{array}{ccccc} & & & & \text { Sample } \\ \text { USA-B } & 1 & 2 & 3 & \text { size } \\ & 44 & 47 & 9 & 153\end{array}$

This overall show of support for indexation seems to stand in contradiction to the apparent lack of public interest in indexation. Possibly, the flow of the preceding questions made it clear that the "correct" answer was the indexed plan, and most respondents did not want to appear foolish. Perhaps more interesting than the answers to question 5 are the explanations of these answers given in response to the following question:

$6(\mathrm{~A}, \mathrm{~B})$. Can you explain why you made the choice that you did in question 5 ?

On the one hand, among respondents who chose the indexed plan, the most common answer to question 6 was some restatement of the basic message of the early questions: indexed plans guarantee real buying power and are safer. On the other hand, there were 103 U.S. 
respondents, but only nine Turkish respondents, who picked the unindexed plan or said they were indifferent.

Reading the answers given by U.S. respondents who chose no indexation in question 5, I conclude that they fall into several major categories. The most common explanation by USA-B respondents who chose the unindexed plan was to refer to the 10 percent inflation forecast, either expressing doubt that inflation would be so high, or saying that they expected to receive more under the unindexed plan: 42 percent of the USA-B respondents who chose no indexation appeared to offer the latter as a reason to prefer unindexed contracts. Only 7 percent of the USA-A respondents who chose the unindexed plan seemed to expect to receive more under that plan. These contrasting results do highlight a tendency for people to be concerned with the expected return on assets, as well as their risk-reduction benefits-and it is rational to have such concerns. The results show that one should not ask whether people want an indexed plan without specifying its terms or expected returns. People are attentive to these details and their answers will be influenced by the assumptions that they make about these details if they are left unspecified in the question.

The most common explanation given by USA-A respondents who chose the unindexed plan (49 percent), and the second most common explanation given by USA-B respondents who did so ( 27 percent), was that nominal contracts are inherently desirable, or indexation is too risky. Their answers include:

Bird in hand is worth two in bush!

It's a safer choice.

I would rather have a fixed increase, than take a chance of a decrease in inflation.

I would rather receive a definite 3 percent increase each year than gamble whether or not the rates will increase or decrease each year.

Yes the sure thing, better than a gamble.

I would like to have a good idea of what I'll be getting, 10 percent will always be 10 percent. But the indexed plan appears to have many unknowns and with that comes fear and apprehension.

Of these, several respondents said that they did not like the possibility that they might see their benefits shrink if inflation were lower than expected; any such decrease would seem unpleasant, unfair, or unwise: 
I would prefer the unindexed plan because even though I would theoretically still be at the same standard of living, I think I would have trouble adjusting to the idea of living on "less" money.

You may at times be lower than what inflation actually is [with the unindexed plan], but it is never good to go backwards.

The next most common explanation, offered by 17 percent of the USA-A respondents and 5 percent of the USA-B respondents who chose the unindexed plan, was doubt that the government inflation numbers were valid for their individual circumstances:

I think some of the government figures are wrong and buy [sic] smart shopping you should be able to adjust.

Aging brings new cost-of-living expenses in goods and services (medical could be disastrous).

If all things have equal choice I would be ok, but in my experience all goods and services would not go down in a free enterprise situation.

The government knows no more about future inflation than I. I picked [answer] 2 just to be safe.

Of these, several respondents thought that the government's national inflation numbers could not be accurate in describing their geographical region:

Figures on inflation are general (nationwide) while true inflation hits the working family where they live (regional).

Index rates must be tied only to the actual location where the income is to be received, i.e., KS inflation could be different than your CT inflation.

There were also several respondents who raised the possibility that the statisticians who compute the government inflation numbers are not to be trusted:

Government statistics are manipulated.

3 percent a year is guaranteed! Government statisticians are stupid and report what there [sic] were told to report.

A few respondents did not believe that the indexed plan would pay out as promised:

I doubt indexed plan would continue to be backed if inflation ran away. 
Index plan is a theory and the way inflation is going social security could not handle the index plan.

And a few seemed to associate indexation schemes with government interference:

It would seem that an unindexed approach leaves us with a little more of a free market.

The Turkish respondents who chose the indexed plan offered similar explanations to those of the Americans in question 6, noting that indexation preserves real buying power. However, there was also a prominent theme of disbelief that inflation in Turkey would be as low as 25 percent a year. One respondent pointed out that a 1996 labor contract by a well-known firm specified a 32.9 percent wage increase for the first six months and another 34 percent for the subsequent six months. Fewer Turkish respondents than Americans chose the unindexed plan or were uncertain, and there are only nine corresponding answers to question 6 . These appear to follow the same general themes as those from the United States, showing a bias toward desiring fixed nominal returns or questioning the relevance of the index to respondents' own situations:

I don't want to be tied to an uncertain inflation rate.

Because the 25 percent increasing plan is more of a guarantee.

In today's Turkey, I wouldn't sign any contract indexed to something because there are always different and abnormal increases.

A couple of these respondents appeared to expect that inflation would be less than 25 percent a year in Turkey:

The experts are not certain. Because of this, instead of increasing, inflation will decrease. Then, it will not be of any use to me.

I believe it will be more profitable.

Four respondents mentioned lack of trust in the government:

Inflation rates prepared by the DIE [government department of statistics] are from time to time adjusted according to government politics. I mean it doesn't seem believable to me. Because of this, I'd choose [answer] 2 instead of the indexed plan.

Because DIE is not trustworthy. 
I don't trust my country.

Nothing will happen in this country.

Some of the Turkish respondents who chose the indexed plan also mentioned concerns that the government cannot be trusted. The apparently higher proportion of Turkish respondents than Americans who lack trust in their government is not surprising. Widespread concern about government corruption in Turkey led to an unusually strong showing by the Islamic Welfare party (Refah) in the December 1995 elections. In July 1996, just before the questionnaire surveys were conducted, Welfare party leader Necmettin Erbakan became prime minister in a coalition government. This is the country's first Islamic government since Mustafa Kemal Atatürk created a modern, secular Turkey in 1923. Political observers interpret the change, in part, as reflecting a broad public perception of corruption or incompetence in the government and the hope that a new government might be different. It is perhaps not clear that concern about government corruption or incompetence would lead one to choose an unindexed contract; on the contrary, corrupt or incompetent officials might be more likely to inflate the currency than to doctor inflation numbers. In any case, this concern apparently has not biased the results of question 5 very far against indexation.

Some economists argue that people may prefer fixed nominal contracts because they have preexisting fixed nominal contracts. The potential significance of this argument is not as great as one might think at first because, as a result of the failure to index, most people avoid strict long-term nominal contracts; pension plans are the major exception. A long-term fixed rate home mortgage is another plausible candidate as a large nominal liability in the U.S. context. However, people can and do refinance their mortgages if inflation - and interest ratesdeclines. People paying or receiving fixed long-term alimony payments might worry about the price level changing, but in such an event their troubles would be limited, since they have the option of modifying their alimony contracts in court. Disabled people like Ms. Walter or retirees on defined benefit plans are rarely locked into any long-term nominal debt, so it is hard to find any evidence of long-term nominal contracts that could cause them not to want their pension or disability benefits indexed. Indeed, none of the answers to question 6 , from either country, 
make any mention of indexation being problematic as a result of preexisting nominal contracts.

\section{Math Anxiety}

Apparently, one reason why people do not respond well to indexation proposals is that these describe payments as determined by a mathematical formula. From the interviews in this survey, it seems that such formulas apparently touch deep anxieties or uncertainties in many people. Even though most questionnaire respondents chose indexation after working some indexation problems, it seems likely that some degree of math anxiety is inhibiting a strong public movement in favor of indexation. It is probably because of these anxieties that most news media avoid mathematics entirely: a newspaper writer will never include a mathematical formula in a story, even though it might enlighten a substantial number of readers.

If people feel that it is very difficult to understand indexation, they will be reticent to introduce it into contracts of any complexity, fearing it to be a distraction or obstacle that will prevent full appreciation of the benefits of the contract. Moreover, if people are never made to understand some of the basic quantitative concepts of indexation fully, they will have difficulty in judging whether a specific indexed contract serves their interests. For example, an ill-informed person might easily misinterpret the difference between the stated yield on a nominal bond and the stated yield on an indexed bond as an "insurance premium" against inflation-induced fluctuations in income, rather than understanding it simply as an expected inflation rate. ${ }^{31}$ This confusion will make indexed bonds appear much less attractive.

To see why people would arrive at the conclusion that indexation is hard to understand, think of the kinds of news stories that they regularly encounter. Some present the level of the Consumer Price Index, a number like 253.2. Many people must feel that they do not know what

31. Some popular accounts of indexed bonds seem to encourage just such confusion. For example, syndicated columnist Stephen Higgins writes: "The obvious point is that these bonds will pay a slightly lower interest rate than conventional Treasury bonds. Analysts estimate the total return will be 3 to 4 percent a year. But conservative investors interested in protecting principal won't necessarily consider that an obstacle." ("A Few Things You Should Know about Inflation Indexed Bonds,', New Haven Register, December 8, 1996, p. F1.) 
this number means. Occasionally there are stories about the various price indexes, perhaps discussing the rebasing of indexes or alleged biases in them. It is easy to see how people might throw up their hands and start to think that it is asking too much to expect them to understand what it is all about.

The survey asks directly about math anxiety in the context of indexation:

7(A). Do you agree with the following statement? "I am not sure that I fully understand all the mathematics of indexation; if I had to sign a contract that had an indexation clause in it, I would feel the need to talk to someone more knowledgeable about indexation." [Please indicate how much you agree, on a scale from 1 to 5.]

1. Strongly agree

2. Agree somewhat

3. Neutral or no opinion

4. Disagree somewhat

5. Strongly disagree

Response in percent

$\begin{array}{lcccccc} & 1 & 2 & 3 & 4 & 5 & \begin{array}{c}\text { Sample } \\ \text { size }\end{array} \\ \text { USA-A } & 30 & 36 & 7 & 17 & 11 & 137 \\ \text { Turkey } & 25 & 49 & 4 & 10 & 12 & 92\end{array}$

7(B). "I feel confident that I understand the mathematics of indexation well; if I had to sign a contract that had an indexation clause in it, I wouldn't feel the need to talk to someone more knowledgeable about indexation."

1. Strongly agree

2. Agree somewhat

3. Neutral or no opinion

4. Disagree somewhat

5. Strongly disagree

Response in percent

$\begin{array}{ccccccc} & & & & & & \text { Sample } \\ \text { USA-B } & 1 & 2 & 3 & 4 & 5 & \text { size } \\ & 32 & 36 & 8 & 14 & 9 & 153\end{array}$

The results are not very enlightening. In questionnaire $\mathrm{A}$ and in the Turkish questionnaire, which suggest that there might be math anxiety, there is some tendency for respondents to agree that it is an issue. But 
in questionnaire $\mathrm{B}$, where the question is reworded to suggest that the respondent might feel confident about such calculations, the answers were reversed. It should be noted that these responses were given by people who had just answered the math problems, and not by the people who threw the questionnaires away.

It seems likely, despite the lack of solid evidence here, that math anxiety is an issue. Various hints of an aversion to mathematical formulae and preference for nominal quantities seemed to come through in the informal interviews but are difficult to incorporate into a questionnaire. It seemed that, in contrast with an abstract mathematical indexation formula, the nominal quantities in unindexed contracts have more tangible value. Perhaps people associate nominal contract payments with stronger mental images of coins and notes-attractive, dignified, finely detailed art objects that have acquired deep, symbolic, cultural value. People seem to attach importance to having cash. Respondents noted, for example, that people all around the world want to hold dollars, or that there is a common consensus about the value of the dollar. Some seemed to be saying that the dollar never loses value, but the economy changes around it. By contrast, to put one's faith in an index number apparently requires trusting some mathematics that only a few, remote people understand. Still, these nuances tended to be fleeting and may disappear under further questioning, so it is hard to know how important they might be in explaining why indexation is not more widespread.

\section{Doubts about the Accuracy of the Consumer Price Index}

Another reason why enthusiasm for indexation is not stronger is that many people do not trust the price indexes. In the interviews, some people expressed mistrust in these numbers, but their remarks were often flippant and hard to interpret. One possibility, suggested by some of the interviewees as well as the answers to question 6 discussed above, is that people think that the numbers might be fraudulent:

8(A). "An important reason not to trust contracts indexed to inflation is that someone in the government might deliberately falsify the inflation numbers to take advantage of people like me."

1. Strongly agree

2. Agree somewhat 
3. Neutral or no opinion

4. Disagree somewhat

5. Strongly disagree

Response in percent

$\begin{array}{lcccccc} & 1 & 2 & 3 & 4 & 5 & \begin{array}{c}\text { Sample } \\ \text { size }\end{array} \\ \text { USA-A } & 21 & 24 & 16 & 27 & 13 & 139 \\ \text { Turkey } & 18 & 43 & 4 & 21 & 13 & 91\end{array}$

8(B). "An important reason to trust contracts indexed to inflation is that those people in the government who are responsible for the inflation numbers are basically honest and trustworthy."

1. Strongly agree

2. Agree somewhat

3. Neutral or no opinion

4. Disagree somewhat

5. Strongly disagree

Response in percent

$\begin{array}{ccccccc} & & & & & & \text { Sample } \\ \text { USA-B } & 1 & 2 & 3 & 4 & 5 & \text { size } \\ & 6 & 29 & 20 & 28 & 18 & 158\end{array}$

The results give some suggestion that fraud might be important, especially in Turkey, where 64 percent agreed at least somewhat. The U.S. answers are not strongly biased toward this opinion, but perhaps it is significant that people are not more uniformly confident in government statistics.

It is also possible that people are skeptical about the inherent value of the numbers, whether or not those who produce them are deliberately fraudulent:

9(A). "The government inflation numbers are almost useless in describing my cost of living increases; the national inflation rate says little about inflation in the things that I tend to buy in the places where I buy them."

1. Strongly agree

2. Agree somewhat

3. Neutral or no opinion

4. Disagree somewhat

5. Strongly disagree 
Response in percent

$\begin{array}{lccrcrc} & & & & & & \text { Sample } \\ \text { USA-A } & 1 & 2 & 3 & 4 & 5 & \text { size } \\ \text { Turkey } & 18 & 32 & 18 & 18 & 8 & 140 \\ & 18 & 36 & 8 & 23 & 15 & 92\end{array}$

9(B). "I believe that the government inflation numbers are pretty accurate in describing my cost of living increases; the national inflation rate accurately describes the inflation in the things that I tend to buy in the places where I buy them."

1. Strongly agree

2. Agree somewhat

3. Neutral or no opinion

4. Disagree somewhat

5. Strongly disagree

Response in percent

$\begin{array}{ccccccc} & & & & & & \text { Sample } \\ \text { USA-B } & 5 & 41 & 12 & 31 & 12 & 157\end{array}$

There was not a lot of agreement to question 9, and when the wording was reversed in questionnaire B, faith in the numbers improved. Indeed, in talking to people about the accuracy of inflation numbers, it appeared that many had a resigned faith, a sense that all prices inevitably march with these numbers.

And yet, despite these answers, there does seem to be widespread mistrust of some sort. The survey pursues the theory that the inflation numbers may be trustworthy now, but that they would become untrustworthy if inflation became very high:

10(A). "When inflation gets very high, prices of individual items jump around a lot more relative to each other, and so the inflation rate becomes a much worse measure of the increase in the cost of living."

1. Strongly agree

2. Agree somewhat

3. Neutral or no opinion

4. Disagree somewhat

5. Strongly disagree 
Response in percent

$\begin{array}{lcccccc} & & & & & & \text { Sample } \\ \text { USA-A } & 1 & 2 & 3 & 4 & 5 & \text { size } \\ \text { Turkey } & 23 & 36 & 29 & 14 & 4 & 139 \\ & 51 & 4 & 15 & 8 & 93\end{array}$

10(B). "When inflation gets very high, prices of individual items tend to fall in line with the inflation rate, all marching up at the same rate, and so the inflation rate becomes a much better measure of the increase in the cost of living."

1. Strongly agree

2. Agree somewhat

3. Neutral or no opinion

4. Disagree somewhat

5. Strongly disagree

Response in percent

$\begin{array}{ccccccc} & & & & & & \text { Sample } \\ \text { USA-B } & 1 & 2 & 3 & 4 & 5 & \text { size } \\ & 11 & 25 & 11 & 37 & 16 & 157\end{array}$

The responses to both versions of question 10 are mildly supportive of the notion that people feel that the accuracy of inflation numbers would be questionable if inflation were high.

Overall, the evidence suggests some tendency to mistrust the inflation numbers, which may be a factor in public resistance to indexation, even if it is not important enough to explain the resistance by itself. If mistrust of published index numbers were the only obstacle, people could define their own indexes for the purposes of their contracts, as the State of Massachusetts did in the very first indexed bond issue, in $1780 . .^{32}$

\section{Perceptions of Substitution Bias}

Some of the respondents in the informal interviews suggested that they avoided most of the effects of inflation by "smart shopping"; that

32. The Massachusetts indexed bond issue of 1780 defined its own price index in terms of four commodities (see note 8). In modern times one could, for example, index long-term contract payments to an average of prices that regularly appear in newspaper advertisements. Thus the index would be given a formal definition without any reliance on government index numbers. 
is, by switching from high-priced full-service stores to discount stores and by avoiding those items that show the greatest increases in prices. If cream cheese becomes expensive, they might switch to peanut butter and not suffer much from the price change. Such reasoning calls to mind the well-known substitution bias in Laspeyres price indexes, such as the U.S. Consumer Price Index.

Laspeyres price indexes are biased toward overestimating the increase in the cost of obtaining a fixed level of utility, so long as relative prices change during the process of inflation. The reason for this bias is that when relative prices change, people can substitute the items that become relatively less expensive for those that become more expensive. A contract that promises that a person will receive a fixed amount in real dollars as measured by the Consumer Price Index allows that person to consume the same market basket as before. Thus the person can be no worse off, and in fact will generally be better off, since relative price changes create opportunities for substitution.

Economists have concluded, however, that in recent U.S. experience the substitution bias has not amounted to much. The U.S. Senate Advisory Commission to Study the Consumer Price Index concludes that the commodity substitution bias is only 0.4 percent a year and the outlet substitution bias is only 0.1 percent a year, for a total bias of 0.5 percent a year. ${ }^{33}$ Jack Triplett concludes that the substitution bias in the U.S. CPI is no greater than 0.1 percent per year. Steven Braithwait estimates this substitution bias at 0.1 percent per year, and Marilyn Manser and Richard McDonald give a range from 0.14 to 0.22 percent per year. Alastair Cunningham's rather lower estimate for the U.K. Retail Price Index, 0.05 percent per year, presumably results from the yearly reweighting of this Laspeyres price index..$^{34}$ Ultimately, the estimates of substitution bias are low because people do not, in fact, tend to shift much of their consumption away from items whose prices have increased more, and also because the variation in relative prices is not very large.

Assuming that people understand the substitution bias at some level, is it possible that they overestimate the extent of the bias?

33. U.S. Senate, Committee on Finance (1996).

34. Triplett (1975); Braithwait (1980); Manser and McDonald (1988); Cunningham (1996). 
11(A). "Even when there is 3 or 4 percent [ 80 to 100 percent] inflation, there are still some prices that go down, or don't go up so much, and someone with fixed income might escape any real effects of inflation just by smart shopping, switching to those items that go up less."

1. Strongly agree

2. Agree somewhat

3. Neutral or no opinion

4. Disagree somewhat

5. Strongly disagree

Response in percent

$\begin{array}{lcccccc} & 1 & 2 & 3 & 4 & 5 & \begin{array}{c}\text { Sample } \\ \text { size }\end{array} \\ \text { USA-A } & 9 & 44 & 5 & 26 & 15 & 138 \\ \text { Turkey } & 4 & 17 & 4 & 25 & 49 & 95\end{array}$

11(B). "When there is 3 or 4 percent inflation, there is no escaping that one needs to have about 3 or 4 percent more income to live as well; there is no way that "smart shopping," trying to switch purchases towards items whose prices are going up less or going down, is going to save you from the ravages of inflation."

1. Strongly agree

2. Agree somewhat

3. Neutral or no opinion

4. Disagree somewhat

5. Strongly disagree

Response in percent

$\begin{array}{ccccccc} & & & & & & \text { Sample } \\ \text { USA-B } & 23 & 34 & 8 & 28 & 6 & \text { size } \\ & 23 & & & \end{array}$

12(A, B). If inflation is 10 percent [100 percent] a year, how much more income does a smart shopper who is a little flexible about what he or she buys need to be just as well off? Please give a number, even if it is only a guess.

$\begin{array}{lcc} & & \text { Sample } \\ \text { USA-A } & \text { Median (percent) } & \text { size } \\ \text { Turkey } & 10 & 136 \\ \text { USA-B } & 100 & 85 \\ & 10 & 154\end{array}$

These answers offer no support for the impression that people think that they can escape the effects of inflation by substituting for other goods. 


\section{Lack of Appreciation of Concavity of Utility Function}

Understanding the welfare benefits of indexation is dependent on knowing the concavity of the utility function over the relevant range. The benefits from indexing to actual inflation, as opposed to grading payments in accordance with expected inflation, are entirely related to risk management, and hence to the concavity of utilities. One might ask whether this concavity is prominent in people's minds. Perhaps their appreciation of the concavity of their utility functions is not automatic; perhaps the concavity must be fairly extreme or vividly illustrated before they are aware of it. They may be accustomed to assessing risk in terms of linear utility unless the importance of concave utility functions is firmly impressed on them.

It is not easy to elicit whether people think about this concavity, but the survey tries a couple of questions. If people reliably make judgments in terms of utility theory, they should be able to recognize that theory when it is stated:

13(A). Which of the following two statements sounds better to you:

1. "Sure I might lose out on an unindexed plan if inflation is higher than expected, but offsetting this, I might win big if inflation is lower than expected. In my mind, it all averages out, so I don't care if I am indexed."

2. "With an unindexed plan, the possibility that I will be a lot poorer if inflation is higher than expected weighs more heavily in my mind than the possibility that I will be a lot richer if inflation is less than expected. Being poorer hurts more than being richer feels good, and thus indexation makes me feel better off on balance.

3. Neither or no opinion

Response in percent

$\begin{array}{lcccc} & & & & \text { Sample } \\ \text { USA-A } & 1 & 2 & 3 & \text { size } \\ \text { Turkey } & 13 & 56 & 32 & 136 \\ & 18 & 68 & 13 & 92\end{array}$

13(B). "Sure I might lose out on an unindexed plan if inflation is higher than expected, but offsetting this, I might win big if inflation is lower than expected. In my mind, as long as indexed plans aren't biased to pay out more or less, I don't care if I am indexed."

1. Strongly agree

2. Agree somewhat 
3. Neutral or no opinion

4. Disagree somewhat

5. Strongly disagree

Response in percent

$\begin{array}{ccccccc} & 1 & 2 & 3 & 4 & 5 & \text { Sample size } \\ \text { USA-B } & 6 & 21 & 32 & 21 & 19 & 155\end{array}$

It must be admitted that respondents did pretty well in choosing the economist's answer to question 13(A); they do seem aware of the implications of concave utility functions. ${ }^{35}$

\section{Prejudice against Indexed Instruments}

Any presumed benefits from indexation that are due to risk reduction might be offset if people think that expected returns are lower on indexed than unindexed contracts. When presented with the possibility of purchasing U.S. government indexed bonds, respondents to the informal interviews often expressed prejudice against them, asserting that such bonds could not be expected to perform well as investments. This leads one to wonder if there might really be public prejudice against indexed bonds, per se. Hence the survey asks following question:

13'(B). How much more money would you expect indexed bonds to pay bond holders, on average, in the long run, when compared to conventional (unindexed) bonds? (This is a question about expected long-run historical average returns, averaging over many different historical periods and investor experiences, not a question about what will happen to any one investor.)

1. Indexed bonds will pay much more on average

2. Indexed bonds will pay somewhat more on average

3. Indexed bonds will pay about the same on average

4. Indexed bonds will pay somewhat less on average

5 . Indexed bonds will pay much less on average

6. Do not know

35. A translation error in question 13(A) on the Turkish questionnaire was brought to my attention after the questionnaire was distributed: the word "richer" in the first sentence of answer 2 was rendered as "poorer." The second sentence of answer 2 was translated correctly. Perhaps respondents realized that the mistranslated sentence made no sense and responded instead to the intended meaning; at least, the similarity between the Turkish and U.S. responses suggests this. 
Response in percent

$\begin{array}{cccccccc} & 1 & 2 & 3 & 4 & 5 & 6 & \text { Sample size } \\ \text { USA-B } & 9 & 33 & 20 & 10 & 1 & 26 & 156\end{array}$

Surprisingly, there was, if anything, a prejudice in the other direction: more people seemed to think that the indexed bonds would pay out more. This result does not support the hypothesis that a prejudice against indexed bonds is a factor diminishing public support for indexation. Possibly, the prejudices voiced in the personal interviews are nothing more than typical investor prejudices about government bonds, rather than attitudes to indexation. It may still be the case that on seeing the lower initial yields that indexed bonds tend to offer, people start to think that they will do less well than unindexed bonds over time.

\section{Lack of Uncertainty about Future Inflation}

For any given concavity of the utility function, indexation is important as a risk management device only if people feel that inflation is fairly uncertain. However, there seems to be some lack of appreciation of the potential for unforecastable price level movements. It is hard to characterize the nature of people's uncertainty about future prices, but the survey tries a couple of questions to this end:

14(A). We want to know how accurately you think that financial experts in America [Turkey] can predict the price level in 2006, ten years from now. Can you tell us, if these experts think that a "market basket" of goods and services that the typical person buys will cost $\$ 1,000[100$ million TL] in 2006 , then you think that it will probably actually cost: between $\$$ _ [TL] and \$_ [TL].

\section{Median ratio}

(high/low)

USA-A

Turkey
$4 / 3$

$3 / 2$
Sample

size

121

76

14(B). How accurately do you think that financial experts in America can predict the price level in 2006, ten years from now? By the price level, we mean the price of all items that people buy, the Consumer Price Index. (This may be a tough question, but we want to gauge how well you think that we really can predict future inflation, so please try to give an answer.)

Experts will probably be accurate within a range of plus or minus percent. 
Respondents report extremely low levels of uncertainty. The Turkish sample's median ratio of 1.5 between high and low estimates, suggesting a 50 percent confidence interval of plus or minus 20 percent, seems especially low. To get some sense of the potential for uncertainty about the price level in Turkey, note that the Turkish CPI increased two and a half-fold between 1964 and 1974, thirty-fold between 1974 and 1984, and 119-fold between 1984 and 1994. If one takes these decades as plausible scenarios for the next decade, one might rather suggest a highto-low ratio of something like $119 / 2.5$, or nearly 50 .

The uncertainty that Americans report is fairly consistent across the two ways of asking the question. This uncertainty is low enough that one might well question whether indexation is a good idea. Suppose, for example, that people have log utility and think that without indexation they have an equal chance of getting an income of one unit and an income of $4 / 3$ units in ten years. By standard expected utility theory, eliminating this risk (replacing the uncertain income in ten years with a certain income of $7 / 6$ units) is worth only about 1 percent of their income in ten years, or of the order of 10 basis points per year for tenyear investments. Thus in deciding whether to invest in indexed bonds, the question whether these will pay more or less, on average, than unindexed instruments will swamp the issue of risk management. Essentially the same conclusion follows from the Turkish responses. With $\log$ utility, people would pay only about 2 percent of income in ten years to replace an equal chance of getting an income of 1.5 units and an income of 1 unit with a sure income of 1.25 units.

\section{Perceived Relevance of Inflation Innovations}

The variability in the CPI numbers does not necessarily represent uncertainty to individuals. The interview responses suggest that people sometimes feel that they already know the future path of that part of the CPI that is relevant to their own experience and that only the measurement error in the CPI is unforecastable. It is hard to write a question that pins down this idea, but the survey tries the following: 
15(B). "People don't know today what the increase in their own cost of living will be next year and for understanding their own cost of living they would learn a lot from next year's inflation numbers if they could get them today.",

1. Strongly agree

2. Agree somewhat

3. Neutral or no opinion

4. Disagree somewhat

5. Strongly disagree

Response in percent

$\begin{array}{ccccccc} & & & & & & \text { Sample } \\ \text { USA-B } & 1 & 2 & 3 & 4 & 5 & \text { size } \\ & 24 & 50 & 14 & 9 & 3 & 156\end{array}$

Respondents tended to agree with this statement, suggesting that information revealed by the Consumer Price Index is generally trusted and contradicting the hypothesis that people do not think that CPI information is relevant to themselves.

\section{Perception That Inflation Harms Working People and Firms}

In another paper on public perceptions of inflation, I conclude that most people think that the real income of working people is harmed by inflation. ${ }^{36}$ Wages are perceived as responding only sluggishly to inflation. This is confirmed by the present survey:

16(A, B). If the government were to become irresponsible with money management and allow the inflation rate to go up so much that prices double [go up ten-fold] (increase by 100 percent $[1,000$ percent]) in the next five years, how much do you think that the income (measured in dollars) of the typical wage earner would go up in the same interval of time? [Note that if income goes up by 100 percent $[1,000$ percent], then in terms of real buying power the wage earner would be unaffected by the inflation, since income goes up just as much as prices.]

1. 200 percent $[2,000$ percent $]$ or more (great increase in real buying power)

2. 150 to 199 percent $[1,500$ to 1,999 percent $]$

3. 120 percent to 149 percent $[1,200$ to 1,499 percent]

4. 80 percent to 119 percent [ 800 to 1,199 percent] (real buying power is about the same)

36. Shiller (1997). 
5. 50 to 79 percent [500 to 799 percent]

6. 0 percent to 49 percent [0 to 499 percent]

7. Less than 0 percent (income in dollars would go down)

Response in percent

$\begin{array}{lcccccccc} & 1 & 2 & 3 & 4 & 5 & 6 & 7 & \begin{array}{c}\text { Sample } \\ \text { size }\end{array} \\ \text { USA-A } & 2 & 1 & 3 & 29 & 36 & 26 & 3 & 131 \\ \text { USA-B } & 3 & 1 & 1 & 15 & 29 & 42 & 9 & 150 \\ \text { Turkey } & 1 & 5 & 5 & 22 & 45 & 12 & 11 & 85\end{array}$

These answers reveal that people have a striking tendency to doubt that incomes will keep up with inflation. This seems to explain a lot about the failure to index. Such a view appears also to explain why people do not index alimony payments. If the father's income is not expected to keep up with inflation, then he cannot be expected to be able to pay the increased alimony. The answers to question 16 do not so directly explain why people do not show more interest in buying government bonds, since in this scenario they are on the receiving side of the equation.

If people think that inflation hurts working people, then one might expect them to think that it helps companies. The survey asks:

$16^{\prime}(\mathrm{B})$. " If there is really a lot of inflation, then companies that promised complete wage indexation (full cost of living allowances) to their employees will probably be in trouble: the companies will have trouble paying all the increased wages out of the money the company is making."

1. Strongly agree

2. Agree somewhat

3. Neutral or no opinion

4. Disagree somewhat

5. Strongly disagree

Response in percent

$\begin{array}{ccccccc} & & & & & & \text { Sample } \\ \text { USA-B } & 29 & 43 & 7 & 15 & 6 & 86\end{array}$

Surprisingly, the weight of the evidence shows that people think that inflation hurts companies too. If this is a valid interpretation, part of the reason that one does not see more COLA clauses in labor contracts might be that people think that these are too big a concession from business to expect. 
This line of thought is perhaps not so surprising, given the tendency of people to think that inflation hurts everybody. ${ }^{37}$ In fact, many people seem to have trouble with the economist's notion that inflation redistributes wealth among people:

17(A, B). Who gets hurt more by unexpectedly high inflation?

1. Creditors (those who lent money)

2. Debtors (those who borrowed money)

3. Don't know

Response in percent

$\begin{array}{lcccc} & & & & \text { Sample } \\ \text { USA-A } & 1 & 2 & 3 & \text { size } \\ \text { USA-B } & 44 & 48 & 8 & 133 \\ \text { Turkey } & 44 & 48 & 9 & 151 \\ & 76 & 21 & 2 & 85\end{array}$

American respondents seemed very unsure about the answer to question 17; responses were almost equally divided between answers 1 and 2 . When those who chose answer 2 were asked in interview to explain why they did so, some replied, essentially, that under a high inflation regime debtors would suffer a decline in real income, which would make it difficult for them to pay their debts. Creditors, people seem to think, are rich bankers, who have the means to ensure that they do not suffer from inflation. ${ }^{38}$ The terms "debtor" and "creditor" are apparently interpreted by many respondents as "poor and middle class" and "rich," respectively. Indeed, respondents tend mainly to use the distinction between the poor and middle class and the rich and rarely talk in terms of debtors and creditors. In light of this, the survey asks:

18(B). Who gets hurt most by unexpectedly high inflation?

1. Poor people

2. The middle class

3. Rich people

4. Don't know

Response in percent

$\begin{array}{cccccc} & & & & & \text { Sample } \\ \text { USA-B } & 1 & 2 & 3 & 4 & \text { size } \\ & 46 & 47 & 3 & 4 & 153\end{array}$

37. See also Shiller (1997).

38. Lippman (1996). 
These results show strong expectations that the rich will not suffer from inflation.

\section{High Inflation Scenarios}

When discussing the possibility of high inflation, interviewees tended to describe such a scenario as involving a great deal of economic chaos and social unrest. This tendency is manifest in the answers to the following question, whose wording was taken, in part, from the mouths of some of the interviewees: ${ }^{39}$

19(A). "If there is high inflation (over 10 percent [200 percent] a year) in the future, it is likely that the inflation will spark economic and social chaos (events such as widespread corporate bankruptcies, riots in the streets, hunger)."

1. Strongly agree

2. Agree somewhat

3. Neutral or no opinion

4. Disagree somewhat

5. Strongly disagree

Response in percent

$\begin{array}{lccrrrr} & & & & & & \text { Sample } \\ \text { USA-A } & 1 & 2 & 3 & 4 & 5 & \text { size } \\ \text { Turkey } & 49 & 42 & 12 & 22 & 12 & 137 \\ & 47 & 7 & 4 & 2 & 89\end{array}$

Respondents show quite strong agreement with question 19. The effect of this belief is probably to reduce support for indexation: if extreme inflation results in such chaos, it is possible that something unforeseen will invalidate an indexed contract. That indexed contracts might be frustrated in such times is investigated below.

\section{Expectations of Government Intervention}

Some of the skepticism about indexed contracts expressed in the interviews seemed to involve doubts about likely future government actions. Although interviewees were not often articulate about this, it appears that people might believe that the government will often, to

39. This tendency is also documented in the tabulation of answers to open-ended questions in Shiller (1997). 
some extent, frustrate the purpose of long-term contracts in attempting to equalize incomes after the fact.

It is well known that the government does frustrate some people's efforts to protect their real incomes, for example, through the progressive tax system and means testing for many government programs and services. Moreover, there is one historical example of the U.S. government effectively repudiating an analogue of indexed government debt: government bonds that promised payment in gold. This occurred in 1933, when the government annulled the gold clause after the price of gold had increased. ${ }^{40}$ Very highly inflationary periods are often also periods of national crisis, and sociologists have noted that calamities tend to cause "sharp reallocation of wealth" and to release " powerful forces tending to rectify economic inequalities." 41 Possibly people feel that such potential government actions weaken the case for indexation. The survey asks:

20(A). "If there is a lot of inflation in the future, then the government won't really allow those people who bought long-term indexed bonds to get any real benefit from the indexation. All the other people who didn't buy the bonds can vote, and they won't tolerate the indexed bond holders making extra money while everyone else is suffering. Under pressure from voters, the government will figure out some tax rule or the like to take the gains from indexation away from indexed bond holders."

1. Strongly agree

2. Agree somewhat

3. Neutral or no opinion

4. Disagree somewhat

5. Strongly disagree

Response in percent

$\begin{array}{lcccccc} & & & & & & \text { Sample } \\ \text { USA-A } & 1 & 2 & 3 & 4 & 5 & \text { size } \\ \text { Turkey } & 11 & 37 & 20 & 21 & 10 & 137 \\ & 8 & 47 & 13 & 23 & 9 & 90\end{array}$

This leading question is turned into an affirmative statement for questionnaire B:

20(B). "If there is a lot of inflation in the future, then I trust that the U.S. government will really allow those people who bought long-term

40. See Cassel (1936) and Hawtrey (1939).

41. Sorokin (1942, pp. 150, 152). 
indexed bonds to get full benefit from the indexation. The government would make sure that no tax law change or other government provision would ever compromise the real purpose of indexation."

1. Strongly agree

2. Agree somewhat

3. Neutral or no opinion

4. Disagree somewhat

5. Strongly disagree

Response in percent

$\begin{array}{ccccccc} & & & & & & \text { Sample } \\ \text { USA-B } & 1 & 2 & 3 & 4 & 5 & \text { size } \\ & 8 & 25 & 14 & 31 & 21 & 154\end{array}$

These results support the notion that people think it somewhat likely that the government will frustrate the purpose of indexation. Most people agree, at least somewhat, with question 20(A). In the questionnaire $\mathrm{B}$ version, most people disagree that the government can be trusted. Note that despite indications that Turkish people are very concerned about corruption in their government, their answers are virtually identical to those of the Americans. Perhaps question 20 is not seen to be about corruption but about powerful political or moral forces in society.

\section{Collective Response Patterns}

Individuals sometimes seem to lack interest in taking actions that might put them ahead of society as a whole, especially if these appear not to conform to customary standards or universally approved behavior. There is a sense of social cohesion in economic vicissitudes; that is, there appears to be a sense of sharing with others, sometimes even resentment of those who think they have outsmarted the others. Sociologists have noted, moreover, a strong tendency for collective response to disaster, and it has been shown above that the prospect of very high inflation appears to be widely perceived as a potential national disaster. ${ }^{42}$

That collective feelings affect market decisions is confirmed by survey work conducted by Maxim Boycko, Vladimir Korobov, and I in various countries. ${ }^{43}$ In the context of such social cohesion, people will

42. On collective response to disaster, see Baker and Chapman (1962).

43. Shiller, Boycko, and Korobov (1991, 1992). 
make economic choices that are commonly recognized as wise and customary, but they may not have an emotional commitment to studying and acting on unusual economic proposals that would set them apart from others. By contrast, an education in economics or business studies seems rather to encourage an attitude of self-congratulation about having made more sensible economic decisions than most people.

It is difficult to study such feelings of social cohesion among the general public in a paper of this scope. I make a weak effort to provide some evidence that noneconomists have such feelings as regards inflation:

21(A). "Somehow, the fact that inflation affects nearly everyone makes the threat of problems created by inflation seem of less concern to me personally; maybe it's shared feeling for other Americans, maybe it's the idea that if we are all in the same boat together none of us feels so bad about lowered buying power because of inflation. Thus I am just not that interested in being one of the few who are protected from the effects of inflation."

1. Strongly agree

2. Agree somewhat

3. Neutral or no opinion

4. Disagree somewhat

5. Strongly disagree

Response in percent

$\begin{array}{lcccccc} & 1 & 2 & 3 & 4 & 5 & \begin{array}{c}\text { Sample } \\ \text { size }\end{array} \\ \text { USA-A } & 2 & 12 & 18 & 28 & 40 & 137 \\ \text { Turkey } & 8 & 26 & 15 & 11 & 40 & 89\end{array}$

Respondents tend to disagree with this statement, contrary to my expectations. The question is reversed for questionnaire $B$, suggesting the opposite answer:

21(B). "Somehow, the fact that inflation affects nearly everyone makes the threat of problems created by inflation seem of more concern to me personally. If we are all in the same boat together, it hurts much more."

1. Strongly agree

2. Agree somewhat

3. Neutral or no opinion

4. Disagree somewhat

5. Strongly disagree 
Response in percent

$\begin{array}{ccccccc} & & & & & & \text { Sample } \\ \text { USA-B } & 1 & 2 & 3 & 4 & 5 & \text { size } \\ & 12 & 31 & 24 & 23 & 9 & 154\end{array}$

Respondents did not tend to disagree with this statement, again, contrary to my expectations. These results of questions 21 (A) and 21(B) are not really supportive of the notion that people are relatively uninterested in taking measures that would set them apart from their friends and neighbors in times of national stress. This issue could be studied with much more care. It is likely that further work would reveal that although such collective feelings do not provide a stand-alone explanation of public resistance to indexation, they do help to explain why there tends not to be action on indexation.

\section{Conclusion}

Economists have been perplexed for a very long time by the public's continuing reliance on long-term nominal contracts in the face of a potential for massive inflation. In the 1830 s Scrope wrote: "And what a farce it surely is to talk of property being effectively protected in a country in which an unseen and secret cause may, within a few years, transfer property to the amount of 1,500 millions from one set of people to another, contrary to the intentions and understanding of the parties?", ${ }_{44}$ Well over a century and a half have gone by, and the farce continues. Is there any hope that the public will one day see the error of their ways and start routinely indexing long-term contracts?

This survey finds that the idea of indexation is indeed not hard for many people to understand. Most respondents were able to articulate the theory of indexation, if asked to do so; most even seemed to embrace the idea of indexation, after having demonstrated their understanding of it. Yet their tendency to accept indexation on the questionnaires only heightens the puzzle, since the general public shows so little interest. The survey response mirrors the understanding of indexation that Irving Fisher seemingly successfully conveyed in business forums in the first

44. Quoted in Fisher (1934, p. 28). 
part of this century, and highlights the frustration that he must have felt when he tried to get action on his proposals for indexation.

I argue that the explanation for the lack of enthusiasm for indexation cannot be monocausal. People have a lot of thoughts about inflation that together conspire to produce the belief that indexation plans are not a very good idea. Economists will continue to be puzzled until they try to appreciate the collective impact of several different aspects of people's world views.

Money illusion does, to some extent, seem to be an important factor in the puzzle. Many people do say, "I want to know how much money I will be getting." And these are often the very people who have just correctly explained how indexation preserves real buying power. Money illusion would be an insubstantial factor in public resistance to indexation if it were nothing more than an impulsive response or a tendency to make mistakes in answering simple questions. In fact, it is probably important because it supports other judgments about the value of indexation.

Notable among the popular notions that reduce the impact of proposals for indexation is a widespread lack of appreciation of the potential uncertainty of inflation. The risk that the price level will be very different than predicted ten years hence is not prominent in people's minds; people give low estimates of this uncertainty, even in a highinflation country such as Turkey. This may be partly due to self-censorship by opinion leaders. It might be thought that describing highinflation scenarios that are of low or moderate probability is not appropriate for normal public discourse. Perhaps opinion leaders fear that they will be seen as shouting fire in a crowded theatre and as promoting the very inflation that is feared. When experts are silent about the potential for bad inflationary outcomes, it is natural that people might forget about these possibilities.

People tend to think of inflation not as causing arbitrary redistributions from debtors to creditors, but as an insidious disease that harms virtually everyone. They tend to believe that individual real incomes are massively eroded by high inflation, harming debtors and creditors, firms and individuals. Thus another factor reducing public support for indexation is the expectation that indexed payments will be very hard to meet, should there be a lot of inflation. In the divorce court, it seems too much to ask that the noncustodial parent must automatically make 
greatly increased payments if inflation picks up a lot. In labor-management disputes, it seems too much to ask that companies increase wages by the full amount dictated by indexation if there is a lot of inflation. As regards private defined benefit pension plans, employees might think it reasonable that their real benefits should decline if inflation picks up and harms the company that they work for.

It is not clear that people are entirely in error to think of inflation in these terms. Historically, inflation has tended to pick up in decades when the real economy is growing less fast, as students of economic growth theory show. ${ }^{45}$ Table 1 reports correlations between inflation rates and growth rates of real GDP. Fourteen of the sixteen estimated correlation coefficients are negative, partly due to the fact that the productivity slowdown that started in the 1970s coincided with a tendency toward higher inflation in many countries. Thus unusually inflationary times have tended also to be bad times for the real economy. Few economists seem to be so aware of this tendency as the general public. There is no clear theory to support such a strong correlation, and the past correlation may be due to particular circumstances that will not be replicated in the future. In a study comparing economists' views of inflation with those of the public, I find that the economists' answers tended to imply that they viewed inflation as merely redistributing income from creditors to debtors, much more than as causing major systemic problems. ${ }^{46}$

The lack of public enthusiasm for indexation is probably also largely due to the impression that indexation has never been a serious topic of discussion. Despite the survey's failure to find that math anxiety is an important issue, I still think that this has inhibited public discussion of indexation. One finds scant mention of inflation risk or indexation in popular books of financial advice, and one has the sense that the author who does mention the topic perceives difficulty in sustaining the reader's interest. Try bringing up personal risk management through indexation at a dinner party and the reaction is likely to be as if the topic were out of bounds, too obscure or technical. Indeed, such an idea is likely to provoke laughter. By contrast, imagine how different the reception would be of an apparently informed and forceful opinion about

45. See, for example, Bruno (1995).

46. Shiller (1997). 
the future direction of the stock market. The public does not react with equal interest to all topics in economics and risk management through indexation must rank low on the list.

Another factor that does appear to contribute to public resistance to indexation is the notion that the government might not really allow the effects of the contract to unfold as planned. This is probably a source of public apathy toward many kinds of long-term planning.

Not all of the suggestions that emerged from the individual interviews as to why people are so indifferent to indexation are sustained by the results of the questionnaires. The written results do not seem to support the hypotheses that people do not understand the implications of concave utility functions, that they are prejudiced against indexed instruments as inherently paying a lower return, or that they have social feelings that reduce their urgency to deal with inflation. It is, probably premature, however, to rule out these ideas altogether.

People in both the United States and Turkey do seem to trust price indexes in one sense: many have a fatalistic belief that nothing can be done to escape the inflation that is measured. Some do express doubts that indexation will work correctly in their own cases, fearing that prices of the goods that they buy will not move with measured inflation. It is plausible that such doubts prey on the minds of more people than express them and may inhibit action, even though the survey finds that, by and large, people do believe the government's inflation numbers, at least in normal times.

The evidence presented here is not entirely negative about the potential for public acceptance of indexation schemes. It is important that questionnaire respondents seemed largely to accept indexation after having worked problems on it. If opinion leaders come across strongly for indexation, emphasizing that there is still substantial risk of high inflation in the future and that unexpected inflation causes unnecessary and arbitrary redistributions, one might expect to see stronger public support for such schemes.

One problem for advocates of indexation is that much of the advice that they give has to be rather complicated. Experts cannot endorse all indexed contracts; indeed, in a period of economic transition, when indexation becomes more prominent, many parties will try to use public confusion about indexation to their own advantage. Indexation is only 
beneficial when it is the outcome of all parties wrestling with the advantages and disadvantages offered by contracting in real terms.

The indexed government debt offered by the United States in January 1997 illustrates well the complexity of the message that must be given to the public. Certainly, experts should not recommend that everyone invest for their retirement in this debt without regard for its yield. The government might issue so few of these bonds that they are overpriced. Moreover, modern portfolio theory does not say that people should save only with indexed bonds, but argues that sophisticated investors should try to hold a market portfolio, using indexed bonds, as the risk-free rate, only to adjust the level of risk in their portfolio to their own preferences. Exclusive reliance on indexed bonds for retirement is simple advice that would only be appropriate for people who are not comfortable with portfolio investing. This is a complicated message, and I do not think that it has ever been conveyed effectively in the media.

Matters become even more complicated if one tries to advise people to take the optimal strategy to hedge their other economic risks. People who believe that the past negative correlation between inflation and real income growth can be extrapolated might try to use nominal contracts to hedge real income risk. ${ }^{47}$ If people in one country wanted to exploit this correlation and use nominal debt as a vehicle for international risk sharing, they would not take on all sorts of nominal long-term contracts with others in their own countries, as seems to be the case at present. Rather, people in one country would short their own country's nominal debt and go long foreign countries' nominal debt-hardly a common practice today. This scenario suggests some moral hazard issues, since governments can create inflation whenever they want it. The optimal management of income risk is a very complex matter for which there are no obvious prescriptions.

But although it cannot simply be said that indexed contracts are always better than unindexed contracts for all parties, the message that a better deal can be struck between parties with indexed contracts than those with nominal contracts ought not to be too difficult to get across to the public, if it is done in a sufficiently cookbook fashion, spelling

47. Kim (1996) argues, based on a theory originated by Lucas (1982), that people should hold nominal debt of foreign countries to hedge risk in their own national income. 
out what is commonly accepted as good procedure. Most people adopt contracts that they believe are standard, trusting to the wisdom of others, and if better provisions come to be accepted as the standard, these will be used.

A pessimistic view of the prospects for widespread indexation of contracts may be warranted, but one should not give up all hope that substantial indexation might somehow be promoted. It may be realistic to hope that in coming decades, current plans might result in a greater proportion of the U.S. national debt being indexed than the roughly 15 percent that is indexed in the United Kingdom. ${ }^{48}$ The United States is a powerful force in international public opinion, and it is possible that the initial steps taken by the U.S. Treasury will motivate public discourse in a more effective way than have the prior steps taken by many foreign governments. One can hope that the example set by the United States may spill over to create a more widespread view around the world that indexation is a sound idea.

Rather than pinning one's hopes on such a possibility, however, one should think of some more radical steps that might be taken to promote indexation. Since government officials apparently cannot commit their successors not to inflate the currency in the future, it is important for governments to encourage the formulation of contracts that protect people against such contingencies. The evidence from this survey suggests that this is better done more transparently than indexation is usually described. The public could be encouraged to write contracts in terms of a "real dollar" or a "contract dollar," thereby cutting out the math anxiety issue induced by index numbers, reframing the discussion solidly in real terms, and perhaps making it seem less likely that contracts will be frustrated by future government actions. This is an old idea, anticipated in the "compensated dollar"' proposed by Simon Newcomb and Irving Fisher. ${ }^{49}$ It has been implemented in Chile, with a unit of account called the unidad de fomento (UF), which is tied to a consumer price index. Chilean prices are often quoted in UF. Such efforts to help the public with the concept of indexation might ultimately produce much wider acceptance.

The most important step that can be taken to encourage the public to

48. See Campbell and Shiller (1996).

49. Newcomb (1879); Irving Fisher (1913). 
accept economists' advice and index various long-term contracts is to institutionalize the practice, write it into codes or standard procedures, as Jevons essentially argued in 1875. One could, indeed, follow Jevons's proposal-although it seems quite a radical step—and pass a law stating that all long-term contracts drawn up after a given date will automatically be indexed, unless they explicitly specify otherwise.

Governments have occasionally shown willingness to issue indexed debt, but they have not done more than offer it. A bolder step would be to eliminate long-term government nominal debt entirely, replacing it with indexed debt. The effect would be dramatic in encouraging public acceptance of indexed debt: this would become the standard. Congress could legislate penalties (such as the partial withdrawal of tax exemptions) for pension plans that offered fixed nominal retirement annuities, encouraging them to substitute indexed annuities. Courts could routinely index alimony, child support, and personal damages settlements. For most of these applications, it would be best to index to an income aggregate, such as national income, rather than the CPI, because of income's better risk-sharing properties. ${ }^{50}$

Other efforts to institutionalize indexation could include indexing wages and salaries, although the case for this idea is perhaps not very strong, since, as noted above, labor negotiations are complicated by strong emotions and rivalrous comparisons that make for downward rigidity in quoted wages. While I believe that it is very important to encourage indexation, the example of labor markets suggests that the methods should be chosen with care.

50. See Shiller and Schneider (1995). See also Brainard and Dolbear (1971), Fischer (1983b), Merton (1983), and Shiller (1993). 


\section{Comments and Discussion}

Charles L. Schultze: This paper reports and interprets the results of a survey carefully designed to dig out the reasons why people do not "see the error of their ways and start routinely indexing long-term contracts." Many of the questions in the survey are ingeniously constructed to test various hypotheses about why indexation is not more popular. The responses and Shiller's analysis provide useful insights into people's attitudes on indexation and inflation, and offer some thoughtful explanations of what lies behind them. In the end, Shiller is so pessimistic about the unwillingness of the private sector to adopt indexation for contracts, but so convinced of its welfare-improving consequences, that he proposes a series of fairly radical governmental mandates and incentives to pull the public, kicking and screaming, toward widespread indexation.

I concentrate on two issues arising from the paper. First, Shiller's survey actually demonstrates substantial support for indexation among those at the receiving end of payments - the demand side of the market for indexation. The resistance to indexation probably stems chiefly from the supply side - the potential issuers of indexed obligations. Their views are not represented in the survey. Second, I suggest some of the potential costs of indexation. The immediate impact of those costs falls on the suppliers of indexed obligations and may explain their resistance to indexation. The existence of such costs should also be seen as qualifications to Shiller's conclusions about the desirability of almost universal indexation. 


\section{The Demand for Indexed Obligations}

It is my reading of the answers to Shiller's survey that those who are on the receiving side of long-term obligations are quite supportive of indexation. Of the twenty-one questions in the survey, only one directly asks how people feel about indexation. The USA-A group of respondents was asked to choose between a pension stream whose nominal annual value would grow at the inflation rate expected by expertsnamely, 3 percent a year-and another stream starting at the same nominal value but indexed to the consumer price index. Sixty-five percent of the respondents chose the indexed stream, compared with only 29 percent who picked the fixed nominal stream ( 7 percent answered that they did not know or were indifferent) - a majority for indexation of $2 \frac{1}{4}$ to 1 .

The USA-B group was asked the same question, except that the inflation rate expected by experts is 10 percent a year. In this group, only 47 percent picked the indexed plan and 44 percent chose the steady nominal stream. But, as Shiller notes, the most common reason given by those in the USA-B group for rejecting the indexed scheme was that they thought the 10 percent expected inflation rate too high, given the current rate of less than 3 percent. Economists are trained to think in terms of unrealistic hypotheticals: assume an economy of perfect competition or a perfect capital market. But even well-educated lay people are much less accustomed to making trade-offs between unrealistic hypotheticals in an unfamiliar field. And so a number of respondents, quite naturally, found a guarantee of 10 percent annual increases in pension benefits a much better deal than an indexed stream. It is almost surely true that had the USA-B group been given the question with the 3 percent inflation forecast, a much bigger majority would have chosen indexation.

This interpretation is strengthened by the Turkish response. The Turkish alternative was posed as a choice between a pension growing at a forecasted inflation rate of 25 percent a year and an indexed system. Given the history of inflation over the past two decades in Turkey, 25 percent appears an unrealistically low inflation forecast. And so Turkish respondents favored the indexed system by an overwhelming 85 to 9 percent margin. It may be partly coincidental, but is nevertheless suggestive, that the USA-B group showed a majority in favor of indexation 
that was 18 percent lower than that of the USA-A group, while the Turkish group had a majority for indexation 20 percent higher than that of the USA-A group. When the question is posed in terms of what respondents believe to be a realistic expected rate of inflation, they consistently prefer indexation by a quite substantial majority, probably about two to one.

An analogous question could have been posed about indexed bonds, asking for a choice between indexed and nonindexed streams of income. It is most likely that respondents, in their role as bond buyers, would have shown a hefty majority for indexed bonds, as they did in the case of pensions.

There are several aspects of the paper that, at first reading, make it appear more pessimistic about demand-side attitudes toward indexation than may really be warranted. For example, substantial space is devoted to exploring the implications of three questions on which a majority or plurality expressed the beliefs that the official price indexes might be rigged by the government, would fail to mirror their own experience, or would become a worse measure of inflation when inflation was high. ${ }^{\prime}$ And another question elicited the response that, confronted with high inflation, the government would somehow weasel out of its obligation. Given these suspicions, the choice of indexation by a two-to-one majority should be taken as a particularly strong endorsement of the concept.

\section{The Supply of Indexed Obligations}

The chief barrier to a more widespread use of indexation apparently does not lie with the potential recipients of indexed payments. Rather, it comes from the potential suppliers, whose views were not included in Shiller's survey. In the short and intermediate run, the issuers of indexed obligations incur risk-bearing costs. These costs will be reflected in the price of the obligations being issued. Had the costs been explicitly reflected in the comparisons presented to survey respondents, the vote for the indexed alternative would presumably have been lower-but then, the puzzle would have partially disappeared.

1. The USA-B group was evenly split on the issue of whether the official price index mirrored their cost of living. 
INDEXED BONDS. Underlying the questions that Shiller poses in his survey and also his policy proposals is the view that except for wages, indexation has no costs. In a world where all surprises were nominal shocks of the immaculate conception type-that is, a monetary disturbance leads to a quick, simultaneous, and equal change in the level or rate of inflation in all prices - there would indeed be no costs to indexation for either party to long-term contracts, only risk-reducing welfare gains. But the literature has long recognized that in the case of supply shocks, indexation can increase the risks borne by issuers of inflation guarantees and can therefore be costly. The discussion has usually been carried on in the context of evaluating the indexation of wages, but it also applies, with differing degrees of importance, to other types of indexation.

Take the case of indexing a private bond issue. There are three reasons why indexation might increase the risks faced by a firm. First, some inflation surprises originate from supply shocks. In such cases, the increase in average product prices that gives rise to an additional nominal obligation under indexation will not be matched by an equivalent increase in a firm's ability to pay. Second, monetary shocks work their way through the economy by complex processes, which, in the transition period, may involve substantial changes in the relative prices and fortunes of individual firms. Moreover, during periods of moderate inflation, a large positive inflation surprise is more likely than a large negative one. For a while, an increase in nominal obligations need not be matched by an increase in ability to pay. Ultimately, with a purely monetary shock, the change in monetary obligations and resources should match, but the indexing firm could face a temporary cash squeeze.

Third, experience teaches that there is often a substantial negative covariance between large inflations and the fortunes of firms. In the medium run, equity prices seem to be negatively correlated with inflation. ${ }^{2}$ This is partly because of the non-neutral effect of inflation on the effective tax rate on capital income (which could be fixed if the tax system were also fully indexed, although at the cost of some substantial complexities). But even without the tax effect, there would be a negative correlation between inflation and equity values, reflecting the fact

2. See, for example, Summers (1981). 
that substantial inflation surprises-whether originating in nominal or real shocks-eventually bring on Federal Reserve stringency accompanied by a period of unused capacity and depressed profits. It may be a coincidence that the period of high inflation in the United States from 1968 to 1982 was accompanied by a fourteen-year bear market in stocks and an almost steady decline in the before-tax return on corporate capital-but I do not think so.

Indexation adds to the risks of firms issuing obligations that come due over the short and medium run, and so has a cost to private issuers, which must be expected to affect the real yield negatively. Buyers of private bonds, in fact, face not a costless trade-off between indexed and unindexed isues, but a choice between the risk reduction afforded by indexed bonds and a higher expected real yield on the unindexed bonds. Surely it is not correct to argue that indexing such long-term contracts is costless and ought to be universally adopted.

This logic obviously does not imply that firms should issue no indexed bonds. As one element in a financial plan, indexing some fraction of fixed liabilities might make sense for a firm, both to take advantage of the dispersion of risk preferences and inflation forecasts among potential buyers and because, in the longer-run, the neutral money shock components of inflation should dominate transitory and supply-side phenomena.

The fact that there have been so few private indexed issues is a puzzle. In a 1983 article, Lawrence Summers shows that during most of the period from the Civil War to the inflation of the late 1960s, nominal bond yields were far too stable to have incorporated a premium systematically reflecting the fluctuations in expected inflation. ${ }^{3}$ And in the sustained inflation of the 1970 s, supply-side shocks were prominent, reducing the attractiveness of indexed bonds to potential issuers. I suspect that these two phenomena may, in part, explain the rarity of indexed private bonds.

Those who take on such long-term obligations as alimony face somewhat the same problem as bond issuers. To the extent that inflation surprises are purely monetary in origin, so that all relative factor and output prices stay unchanged, indexation would be welfare-improving for both parties. But in the short and intermediate run, inflation is

3. Summers (1983). 
sometimes far from neutral with respect to relative prices and inflation risks may not be symmetrical. While indexation that costs the recipient nothing may be unambiguously welfare-improving for that recipient, it can be risk-increasing for the payer.

PRIVATE PENSIONS. I confine my attention here to the question of indexing pensions during a worker's retirement years. ${ }^{4}$ Few, if any, private pension plans provide a nominal annual benefit that increases each year by a fixed amount, according to the inflation rate expected when the pension begins. Rather, most pension plans simply provide a fixed nominal annual amount, whose magnitude is determined in a variety of ways (although during the high-inflation years 1977-82, about half of large and mid-sized firms did grant increases to cover at least a modest fraction of the inflation that had occured). But for simplicity, assume that one is comparing an indexed plan and an unindexed plan of equal nominal expected present value, when calculated at the expected rate of inflation.

Currently, a private firm could match its indexed pension obligations with an appropriate accumulation of indexed Treasury bonds and, to a first approximation, avoid any increased risk. But if, like most firms, it prefers to fund its pension plan with a mixed portfolio that includes private stocks and bonds, indexing the plan could put it in a worse position in terms of the trade-off between risk and returns. Even if private indexed bonds were available, for the reasons discussed above there would be some cost, by way of a lower real return. And stocks are not a good hedge for inflation in the short and intermediate term. The schedule of risk-return opportunities for funding the indexed obligations would pivot in an unfavorable direction. And to the extent the firm's pension plan is not fully funded, the risks associated with the residual obligation will tend to increase, for the three reasons listed above in the discussion of the costs of indexed bonds. The cost of providing the indexed plan would rise, and presumably this would eventually be reflected in the compensation package. On balance, the change might still be worthwhile from the pensioners' viewpoint, but it may not be costless.

4. Munnell (1979) spells out the significant difficulties faced by private firms in providing inflation protection in pension formulas during the working life of an individual, given the substantial number of job changes that the typical worker makes during his or her career. 
The situation is yet more complicated. Inflation is only one of the portfolio risks that retirees face. As Summers has pointed out, retirees ought to be interested in optimizing the real risk-return characteristics of their overall portfolios in the light of their own preferences. If the inflation risk associated with their pensions is removed by indexation, they will wish to add risk elsewhere, so as to shift their portfolios back toward the old risk-return balance. ${ }^{5}$ But for the many retirees with limited nonpension assets, that may be a very circumscribed option.

In sum, given the existence of a basic social security pension indexed to inflation, public policy ought not to be devising tax penalties to push private firms with defined benefit pension plans toward inflation indexing, as Shiller urges. Rather, it should encourage the continuation of the current shift toward defined contribution plans, under which retirees can optimize across a wide range of risk-return options, presumably with safeguards against hasty and uninformed actions. Their portfolios could certainly include indexed Treasury securities. As a side benefit, defined contribution pension plans would greatly simplify the task of making pensions portable for a mobile work force.

\section{Some Final Thoughts}

Shiller recognizes that indexing wages could cause some problems and excludes wages from his otherwise universal recommendations for indexation. But it is certainly possible that if public policy were successful in getting the public to think exclusively in terms of indexation, this habit of thought would affect the attitudes about wages that underlie the informal and implicit contracts governing longer-term employment relationships. The fact that in the American economy real wage cuts are accepted through inflation erosion, in circumstances where nominal cuts are strongly resisted, provides flexibility in relative real wages that keeps the nonaccelerating inflation rate of unemployment lower than that in Europe, where workers do think more explicitly in indexed terms and where resistance to wage cuts takes the form of real wage rigidity.

As an aside, Shiller suggests in his penultimate paragraph that it would be preferable to index many types of long-term obligations to national income rather than to prices. Indexing payment streams to national income would require issuers of indexed obligations to hedge

5. Summers (1982, pp. 1, 14). 
them in a thick and well-developed worldwide market for income claims. I have neither the time nor the necessary familiarity with the recent literature on the creation of macromarkets, some of it produced by Shiller himself, to deal with this issue. But my cursory look at some of this literature suggests that if one waits until such markets develop, indexation will be a long time coming. On balance, Shiller successfully makes the case that the indexation of long-term obligations is too little practised. But he overstates the potential net benefits from the spread of indexation and his policy proposals go too far.

Robert E. Hall: In this paper, Robert Shiller bravely tackles an important piece of the puzzle of nominal contracting. He asks why contracts are so often stated in monetary terms when, over history, almost every monetary unit has been drastically unstable. Indexation of contracts to the cost of living provides a simple and inexpensive way around the perils of the nominal contract, yet surprisingly few contracts are indexed. Shiller brings a lot of new evidence to the discussion.

This issue divides the Woodward-Hall household. Susan Woodward has worked hard to build the infrastructure for indexation, especially in the key area of mortgages, whereas I have put my efforts into pushing schemes to make the dollar so stable that indexation would be unnecessary. One or the other should be out of this business within the next decade.

The most interesting findings of Shiller's paper are as follows:

-Over the horizon relevant for personal financial planning-ten, twenty, or more years-dispersion in the price level has historically been huge in both the United States and Turkey (see table 1). Nevertheless, people seem to believe that prospective dispersion will be tiny (see questions 14A, 14B).

-Indexation is close to costless. There are no significant legal barriers. People understand inflation and indexation. They do not see the mathematics as a serious obstacle. They strongly prefer indexation in an abstract hypothetical setting, when the choice is fair.

- People see graduation - adjustment for expected future inflationas an important part of the benefit of indexation, as one would expect, given their understatement of uncertainty about inflation.

-Other than TIPS (the new indexed bonds sold by the U.S. Treasury) and some private debt, little debt is indexed in the United States 
or in Turkey. Indexation of wages is a familiar idea, but the practice is rare in the United States today. By far the biggest element of indexation in the U.S. economy is social security payments.

- The recently issued TIPS are held not by individuals but by institutions.

- In both the Ünited States and Turkey, people use short-term contracts with frequent renegotiation in circumstances where long-run indexed contracts would serve their purposes better.

-People trust the dollar, and even the Turkish lira, and are skeptical that the cost of living will be properly measured or that the government would permit the large adjustments that would occur in highly inflationary times.

-As is apparent in Shiller's earlier work, the public holds a completely different view of inflation from a monetary economist. In the public's view, inflation occurs when the economy falls apart and all groups suffer lower real income. In particular, wages do not rise in parallel with prices.

Shiller's most important conclusion, by far, is that the public grossly understates the prospective dispersion of the price level. This misunderstanding is the biggest obstacle to indexation: the public seriously underestimates the prospective benefits of indexation. Another important conclusion is that indexed debt and other indexed contracts lack credibility. Shiller's analysis also emphasizes that the government and personal financial advisers do not push indexation as the solution to personal financial problems. The bottom line is that there should be much more aggressive federal sponsorship of widespread indexation to correct the public's ignorant lack of interest. The government should introduce an unidad de fomento, like that in Chile. All federal debt should be indexed.

Shiller's discussion of the unidad de fomento is commendable, but he should have given it more attention. The UF has delivered effortless indexation of all forward transactions in Chile. In brief, the UF is an abstract monetary unit without any corresponding medium of exchange. Transactions are carried out in pesos, which are provided by a standard central bank setup. The UF is defined as enough pesos to buy the cost of living bundle. Each day, a box in the lower right corner of the financial page of every Chilean newspaper reports the day's peso content of the UF. All forward contracts, without exception, are stated in 
UF's-savings accounts, leases, employment contracts, mortgages, and so forth. When the time comes to make a payment on an obligation, the UF amount is multiplied by that day's peso content of the UF, and the payment is made in pesos. The Chilean public shifted quickly to the system in 1980 and has used it ever since. The UF's character as a monetary unit rather than an indexation scheme is apparently the secret of its success. Why does the public accept an alternative real monetary unit so easily when indexation is such a hard sell? It is equally difficult to say why the system has not been adopted in any other country. During recent monetary reforms in Argentina and Brazil, there was public debate on adopting a unidad de fomento, but I believe that Chile is still the only country enjoying the benefits of easy universal indexation.

Shiller concentrates on individual views about inflation and the potential safeguard from indexation. It is worth mentioning how different the situation is at the business level. Indexation is the rule, not the exception, in business-to-business contracts. CPI indexation is rare, but indexation to cost indexes for suppliers is close to universal in longer term contracts.

Shiller focuses on the general public and its devotion to nominal forward contracts. Other pockets of devotion also provide obstacles to indexation. Bankers have huge amounts of experience with nominal deals and none with real ones. And, as Shiller notes but does not pursue, the financial press is an absolutely consistent source of misinformation about indexation.

$\mathrm{He}$ is persuasive that public demand will not deliver beneficial indexation in the United States, nor even in Turkey. He gives too little attention to push from the suppliers of indexed financial arrangements. Here, the history of adjustable rate mortgages is instructive. Prospective homeowners did not go to banks and ask for mortgages indexed to interest rates. The public has always favored fixed-rate mortgages with the same determination that Shiller shows it favors nominal rather than real payments. Adjustable rate mortgages were pushed into the mortgage market by institutions that found it profitable to originate them and then package them for the secondary market. The same would happen with mortgages indexed to price levels.

Shiller downplays indexation issues in pensions. First, his statement that military pensions and social security payments alone are indexed is correct only in a narrow sense. Defined benefit plans generally tie 
retirement benefits to final-year earnings. Also, many firms make adjustments to benefits on the basis of subsequent inflation, even though there is no contractual requirement to do so. As a result, pension funds are the natural purchasers of indexed government debt, in order to hedge their real pension obligations.

As Shiller's work shows-both in this and earlier papers-Americans love the dollar. They use it excessively. Shiller's answer to the public's resistance to indexation is a huge national investment in creating indexed financial products and training people to use them as alternatives to the dollar. Surely an American unidad de fomento should be considered as an alternative. But there is also another answer: change the dollar so that it provides the benefits of indexation without altering the characteristics that are comfortable and familiar to the public. Alan Greenspan has made a lot of progress along these lines. Shiller quite properly stresses uncertainty about the purchasing power of the dollar over intervals of decades. There is no reason to doubt the Federal Reserve's ability to stabilize the dollar to the extent that the twentyyear-ahead conditional distribution of the CPI has a mean equal to the current value of the CPI and a standard deviation of less than 4 percent. In other words, it is easily within the Fed's grasp to validate the tight conditional distribution that people actually hold, despite its historical inaccuracy. It would be a mistake for the Fed to promise to keep the price level close to a prescribed target each year-because of occasional inflationary shocks - but it would be reasonable to ask the Fed to nudge the price level back toward target each year, so that the twenty-yearahead conditional distribution has a mean equal to the target level and little dispersion. The Greenspan Fed is coming close to this ideal.

The real problem - as Shiller is obviously aware-is that there is no guarantee that the Fed will not fall back into the hands of the kind of people who permitted the extreme dispersion of the price level shown in table 1. The public's suspicion about the viability of indexation is supported by one important episode in U.S. history: in 1933 the government removed indexation provisions from private contracts; gold clauses, which effectively caused future payments to be made in gold, were invalidated in contracts already in effect and prohibited in new contracts. Note that the issue in this case is a little different from the main concern that Shiller considers: the shielding of debtors is common to both, but not the removal of cost of living indexation. Respondents 
to his survey doubt that the government would permit the increase in the burden on debtors that indexation would bring in the case of high inflation. In 1933 the government did not permit the increase in the burden on debtors that would have occurred as a result of an increase in the dollar price of gold. Had contracts been indexed to the cost of living rather than to gold, indexation would have protected debtors, and surely the government would not have stepped in.

Shiller's paper invites dabbling in explanations of the public's devotion to the national monetary unit, and I cannot resist. First, I reiterate the importance of his point that the public constantly hears that the dollar is the right way to think about future value and is hardly ever taught to think in real terms. One of the first steps in teaching intertemporal economics is to get students out of this mode, so grown-up economists cannot understand why the public thinks differently. Second, the public sees the monetary unit of value in just the same light as other publicly defined units of weight and measure. Even economists would have trouble switching to a world where the length of the mile, the weight of a pound, and the duration of an hour were determined as policy variables and had huge amounts of dispersion over ten- or twenty-year periods. If these units were unstable, the Shillers (and Woodwards) of the profession would advocate the indexation of contracts stated in miles, pounds, or hours. But surely our current approach is better. People write contracts in these units with no fear that they will change. And the public thinks that the dollar has the same property. So why not indulge this belief by adopting a monetary policy that keeps the purchasing power of the dollar in a band of a few percentage points around a prescribed constant?

General discussion: James Duesenberry suggested that one reason why people may not like indexation could be confusion about whether indexation would be full or partial; indexing alimony when wages are not indexed could increase, rather than decrease, an individual's risk. Shiller noted that the supposition that people dislike bond indexation because some of their other contracts are not indexed is not supported by the survey data: not a single person gave such an explanation. Robert Moffitt pointed out that the indexation of child support payments to inflation would be unnecessary if support payments were indexed to the wages of the parent making the payments. But Robert Hall thought that 
such a system was inferior to indexation because, like a tax, it would create adverse incentives. Benjamin Friedman suggested that the lack of markets in indexed securities might not reflect an absence of potential demand. The standard Wall Street line is that securities are not bought, they are sold. So the question "Why don't people want to buy indexed securities?" could be asked about any product. The more relevant question is, "Why aren't the issuers or the investment bankers pushing this product?' Sales will grow only when the financial industry devotes itself to making a sales pitch. He speculated that as the supply of indexed bonds rose, they would be appropriately priced and marketed.

Friedman also mentioned Zvi Bodie's argument that the inflation risk facing wealth owners with long horizons can be largely eliminated by investing in short-term debt investments and rolling over the portfolio. Although that investment strategy risks changes in the real rate of interest, that risk is relatively minor as compared with the risk due to inflation on long-term nominal bonds. Hence the value of indexation may be less than Shiller suggests. In a similar vein, Ben Bernanke noted that Shiller assumes that real bonds are strictly preferable to nominal bonds, which may or may not be true, depending on the individual's portfolio. So the puzzle to be solved is one of a broader set of portfolio puzzles, and, by his own logic, Shiller should advocate government intervention forcing people to optimize their portfolios in other ways, too!

Friedman suggested that some of the survey results about people's dislike of inflation could reflect the fact that to many people, "inflation" simply means "bad times" - falling incomes or profits or increased unemployment. If people are feeling more vulnerable these days, as some surveys suggest, they may be fearful of any number of possible "bads." Moffitt added that the hypothesis of workers' increased feeling of vulnerability is consistent with actual experience, such as the increase in the variance of transitory earnings in the United States in the 1980s.

Katherine Abraham was distressed by Shiller's findings of public distrust of government agencies. If 45 percent of the public does not trust government data, there is a major credibility problem. She noted that the BLS has instituted many procedures attempting to insulate its statistics from politics and hoped this would assure the public that its indexes are not subject to political manipulation. The Bureau of Labor 
Statistics avoids capricious changes in methods-and indeed, has been criticized for moving too slowly-believing that moving with deliberate speed should help to ensure trust in the numbers produced. It should be possible to encourage critical and constructive discussion without undermining public confidence in the data. But she wondered whether some of the public's current mistrust was a spill-over from the CPI debate, which has grown from a scientific debate to national news, with headlines announcing deep problems with the CPI. Charles Schultze believed the mistrust of government responses related to government in general, and not to a particular agency. When asked whether they would agree or disagree that the government would make sure that no tax law change or other provision would ever compromise the real purpose of indexation, he did not find it surprising that almost all respondents disagreed. Jonathan Gruber questioned the assumption of Shiller's survey that people have sufficient mathematical ability to evaluate the results of inflation or indexing. He noted other surveys showing that around a third of the public cannot add up a restaurant check, and asked whether those who responded to the survey were better educated than average, and hence not representative? Shiller indicated that the respondents were quite well educated-even in Turkey, half the respondents had some college education. Bernanke cautioned that Islamic codes on the financial system may influence some of the Turkish answers.

Duesenberry urged careful thought about the effect of indexation on the aggregate behavior of the economy. If monetary and fiscal authorities are prone to mistakes, or the economy is subject to external supply shocks, indexation could amplify the problem, creating a less stable, and possibly more inflationary, economy. He noted that Brazil provides an example of indexation run amok. The Brazilian experience also raises the question of how indexation would affect a government's debt structure and interest payments. Gruber agreed that indexation might alter the dynamics of the economy. In his research he has found that the costs of many employer mandates from the government are fully passed on to real wages, not through nominal wage cuts but through price increases. If the economy were fully indexed, this method of passing on costs would be removed. The adjustment of real wages would have to take place by some other, possibly more costly, mechanism. 


\section{References}

Akerlof, George A., William T. Dickens, and George L. Perry. 1996. "The Macroeconomics of Low Inflation." BPEA, 1:1996, pp. 1-77.

Baker, George W., and Dwight W. Chapman. 1962. Man and Society in Disaster. Basic Books.

Bodie, Zvi. 1990. "Inflation Insurance.' Journal of Risk and Insurance 57(4):634-45.

$\rightarrow$ Brainard, William, and F. T. Dolbear. 1971. "Social Risk and Financial Markets." American Economic Review, Papers and Proceedings 61(2): 36070.

Braithwait, Steven D. 1980. "The Substitution Bias of the Laspeyres Price Index: An Analysis Using Estimated Cost-of-Living Indexes." American Economic Review 70(1): 64-77.

Bruno, Michael. 1995. 'Does Inflation Really Lower Growth?' Finance and Development 32(3): 35-38.

Campbell, John Y., and Robert J. Shiller. 1996. "A Scorecard for Indexed Government Debt." In NBER Macroeconomics Annual 1996, edited by Ben S. Bernanke and Julio J. Rotemberg. MIT Press.

Card, David, and Dean Hyslop. 1997. "Does Inflation Grease the Wheels of the Labor Market?"' In Reducing Inflation: Motivation and Strategy, edited by Christina D. Romer and David H. Romer. University of Chicago Press.

Cassel, Gustav. 1936. The Downfall of the Gold Standard. Oxford: Clarendon Press.

Cavallo, Domingo F. 1983. "Comments on Indexation and Stability from an Observer of the Argentinean Economy." In Inflation, Debt, and Indexation, edited by Rudiger Dornbusch and Mario Henrique Simonson. MIT Press.

Cunnningham, Alastair W. F. 1996. "Measurement Bias in Price Indices: An Application to the UK's RPI." Working Paper 47. London: Bank of England (March).

Featherstone, Mike. 1990. Global Culture: Nationalism, Globalization, and Modernity. London: Sage Publications.

Fischer, Stanley. 1983a. "On the Nonexistence of Privately Issued Index Bonds in the U.S. Capital Market." In Inflation, Debt, and Indexation, edited by Rudiger Dornbusch and Mario Henrique Simonsen. MIT Press.

- 1983b. "Welfare Aspects of Government Issue of Indexed Bonds." In Inflation, Debt, and Indexation, edited by Rudiger Dornbusch and Mario Henrique Simonsen. MIT Press.

- 1986. Indexing, Inflation, and Economic Policy. MIT Press.

Fisher, Irving. 1913. “'A Compensated Dollar.' Quarterly Journal of Economics 27(February): 213-35.

1928. The Money Illusion. New York: Adelphi. 
1934. Stable Money: A History of the Movement. New York: Adelphi.

Fisher, Willard C. 1913. "The Tabular Standard in Massachusetts History." Quarterly Journal of Economics 27(May): 417-51.

Friedman, Milton. 1974. "Monetary Correction." In Essays on Inflation and Indexation. Washington: American Enterprise Institute.

Groshen, Erica, and Mark Schweitzer. 1995. "The Effects of Inflation on Wage Adjustments in Firm-Level Data: Grease or Sand?" Unpublished paper. Federal Reserve Bank of New York.

Hawtrey, R. G. 1939. The Gold Standard in Theory and Practice, 4th ed. London: Longman, Green, and Co.

Jevons, William Stanley. 1875. Money and the Mechanism of Exchange. New York: D. Appleton.

Kim, Soyoung. 1996. "Essays in Monetary Policy and Finance in Open Economies." Ph.D. dissertation. Yale University.

Lippman, John. 1996. "Public Understanding of Inflation and Indexation." Unpublished paper. Yale University (April).

Lowe, Joseph. 1822. The Present State of England in Regard to Agriculture, Trade, and Finance. Reprint. New York: Augustus M. Kelley, 1967.

Lucas, Robert E. Jr. 1982. "Interest Rates and Currency Prices in a TwoCountry World." Journal of Monetary Economics 10(3): 335-59.

McCulloch, J. Huston. 1980. "The Ban on Indexed Bonds, 1933-77." American Economic Review 70(5): 1018-21.

Manser, Marilyn E., and Richard J. McDonald. 1988. "An Analysis of Substitution Bias in Measuring Inflation, 1959-85." Econometrica 56(4): 90930.

Merton, Robert C. 1983. "On Consumption Indexed Public Pension Plans." In Financial Aspects of the United States Pension System, edited by Zvi Body and John B. Shoven. University of Chicago Press.

Munnell, Alicia H. 1979. "The Impact of Inflation on Private Pensions." New England Economic Review 79(March-April): 18-31.

Newcomb, Simon. 1879. "The Standard of Value." North American Review September: 223-37.

Shafir, Eldar, Peter Diamond, and Amos Tversky. 1997. "On Money Illusion." Quarterly Journal of Economics (forthcoming).

Shiller, Robert J. 1993. Macro Markets: Creating Institutions for Managing Society's Largest Economic Risks. Oxford University Press.

- 1997. "Why Do People Dislike Inflation?" In Reducing Inflation: Motivation and Strategy, edited by Christina D. Romer and David H. Romer. University of Chicago Press.

Shiller, Robert J., Maxim Boycko, and Vladimir Korobov. 1991. "Popular Attitudes toward Free Markets: The Soviet Union and the United States Compared.' American Economic Review 81(3): 385-400. 
1992. "Hunting for Homo Sovieticus: Situational versus Attitudinal Factors in Economic Behavior." BPEA, 1:1992, 127-94.

Shiller, Robert J., and Ryan Schneider. 1995. "Labor Income Indices Designed for Use in Contracts Promoting Income Risk Management." Working Paper 5254. Cambridge, Mass.: National Bureau of Economic Research (September).

Siegel, Jeremy J. 1994. Stocks for the Long Run: A Guide to Selecting Markets for Long-Term Growth. Burr Ridge, Ill.: Irwin Professional.

Sorokin, Pitirim A. 1942. Man and Society in Calamity: The Effects of War, Revolution, Famine, Pestilence upon Human Mind, Behavior, Social Organization and Cultural Life. E. P. Dutton.

Summers, Lawrence H. 1981. "Inflation and the Value of Corporate Equities." Working Paper 824. Cambridge, Mass.: National Bureau of Economic Research (December).

- 1982. "Observations on the Indexation of Old Age Pensions." Working Paper 1023. Cambridge, Mass.: National Bureau of Economic Research (November).

- 1983. "The Nonadjustment of Nominal Interest Rates: A Study of the Fisher Effect.' In Macroeconomics, Prices, and Quantities: Essays in Memory of Arthur M. Okun, edited by James Tobin. Brookings.

Tobin, James. 1971. "An Essay on the Principles of Debt Management." In Essays in Economics, vol. 1, Macroeconomics, edited by James Tobin. Chicago, Ill.: Markham.

Triplett, Jack E. 1975. "The Measurement of Inflation: A Survey of Research on the Accuracy of Price Indexes." In Analysis of Inflation, edited by Paul H. Earl. Lexington, Mass.: Lexington.

U.S. Senate. Committee on Finance. 1996. Final Report of the Advisory Commission to Study the Consumer Price Index. S. Prt. 104-72, 104 Cong., 2 sess. Government Printing Office.

Wilson, Robert D. 1980. "Inflation-Proof Child Support Decrees: Trajectory to a Polestar." Iowa Law Review 66(1): 131-52. 